\title{
Analysis of CCN activity of Arctic aerosol and Canadian biomass burning during summer 2008
}

\author{
T. L. Lathem ${ }^{1}$, A. J. Beyersdorf ${ }^{2}$, K. L. Thornhill ${ }^{2,3}$, E. L. Winstead ${ }^{2,3}$, M. J. Cubison ${ }^{4, *}$, A. Hecobian ${ }^{1, * *}$, \\ J. L. Jimenez ${ }^{4}$, R. J. Weber ${ }^{1}$, B. E. Anderson ${ }^{2}$, and A. Nenes ${ }^{1,5}$ \\ ${ }^{1}$ School of Earth and Atmospheric Sciences, Georgia Institute of Technology, Atlanta, Georgia, USA \\ ${ }^{2}$ NASA Langley Research Center, Hampton, Virginia, USA \\ ${ }^{3}$ Science Systems and Applications, Inc., Hampton, Virginia, USA \\ ${ }^{4}$ Cooperative Institute for Research in Environmental Sciences (CIRES) and Department of Chemistry and Biochemistry, \\ University of Colorado at Boulder, Boulder, Colorado, USA \\ ${ }^{5}$ School of Chemical and Biomolecular Engineering, Georgia Institute of Technology, Atlanta, Georgia, USA \\ * now at: Tofwerk AG, Thun, Switzerland \\ ** now at: Department of Atmospheric Science, Colorado State University, Fort Collins, Colorado, USA
}

Correspondence to: A. Nenes (athanasios.nenes@gatech.edu)

Received: 1 September 2012 - Published in Atmos. Chem. Phys. Discuss.: 20 September 2012

Revised: 7 February 2013 - Accepted: 25 February 2013 - Published: 8 March 2013

\begin{abstract}
The NASA DC-8 aircraft characterized the aerosol properties, chemical composition, and cloud condensation nuclei (CCN) concentrations of the summertime Arctic during the 2008 NASA Arctic Research of the Composition of the Troposphere from Aircraft and Satellites (ARCTAS) campaign. Air masses characteristic of fresh and aged biomass burning, boreal forest, Arctic background, and anthropogenic industrial pollution were sampled. Observations were spatially extensive $\left(50-85^{\circ} \mathrm{N}\right.$ and $\left.40-130^{\circ} \mathrm{W}\right)$ and exhibit significant variability in aerosol and $\mathrm{CCN}$ concentrations. The chemical composition was dominated by highly oxidized organics (66-94\% by volume), with a water-soluble mass fraction of more than $50 \%$. The aerosol hygroscopicity parameter, $\kappa$, ranged between $\kappa=0.08-0.32$ for all air mass types. Industrial pollution had the lowest $\kappa$ of $0.08 \pm 0.01$, while the Arctic background had the highest and most variable $\kappa$ of $0.32 \pm 0.21$, resulting from a lower and more variable organic fraction. Both fresh and aged (long-range transported) biomass burning air masses exhibited remarkably similar $\kappa(0.18 \pm 0.13)$, consistent with observed rapid chemical and physical aging of smoke emissions in the atmosphere, even in the vicinity of fresh fires. The organic hygroscopicity $\left(\kappa_{\text {org }}\right)$ was parameterized by the volume fraction of water-soluble organic matter ( $\left.\varepsilon_{\mathrm{WSOM}}\right)$, with a $\kappa=0.12$, such that $\kappa_{\mathrm{org}}=0.12 \varepsilon_{\mathrm{WSOM}}$. Assuming bulk (size-independent)
\end{abstract}

composition and including the $\kappa_{\text {org }}$ parameterization enabled CCN predictions to within $30 \%$ accuracy for nearly all environments sampled. The only exception was for industrial pollution from Canadian oil sands exploration, where an external mixture and size-dependent composition was required. Aerosol mixing state assumptions (internal vs. external) in all other environments did not significantly affect $\mathrm{CCN}$ predictions; however, the external mixing assumption provided the best results, even though the available observations could not determine the true degree of external mixing and therefore may not always be representative of the environments sampled. No correlation was observed between $\kappa_{\text {org }}$ and $\mathrm{O}: \mathrm{C}$. A novel correction of the $\mathrm{CCN}$ instrument supersaturation for water vapor depletion, resulting from high concentrations of CCN, was also employed. This correction was especially important for fresh biomass burning plumes where concentrations exceeded $1.5 \times 10^{4} \mathrm{~cm}^{-3}$ and introduced supersaturation depletions of $\geq 25 \%$. Not accounting for supersaturation depletion in these high concentration environments would therefore bias CCN closure up to $25 \%$ and inferred $\kappa$ by up to $50 \%$. 


\section{Introduction}

The Arctic is a particularly vulnerable region of Earth with a large warming trend and high sensitivity to climate forcing (Law and Stohl, 2007; Shindell and Faluvegi, 2009; Screen et al., 2012), largely due to the strong albedo-sea ice feedback. Aerosol species have the potential to modify these critical feedbacks and affect the sea ice albedo by altering the heat balance of the atmosphere and surface, either directly through their ability to scatter and absorb solar radiation, or indirectly through their ability to uptake atmospheric water vapor and form cloud droplets and ice crystals. It is well known that the Arctic environment can accumulate aerosol through pollution transported from northern mid-latitude continents, with Arctic haze, black carbon deposition onto snow and bioaccumulation of heavy metals (e.g., mercury) being observed (Jacob et al., 2010). As industrial activities expand toward the mid-latitudes and higher Arctic, their closer proximity and emissions may further accelerate Arctic warming. There is an urgent need to characterize the source of these pollutants in the Arctic environment, to understand their physical and chemical properties, their evolution over time, and what direct and indirect impacts they may have on regional and global climate (Jacob et al., 2010).

The Arctic atmosphere is affected by three dominant sources of aerosol pollution: (1) long range transport of emissions from mid-latitude continents, (2) biomass burning emissions from summertime boreal forest fires in North America and Eurasia, and, (3) natural or anthropogenic sources in the Arctic. The transport of pollution from midlatitude continents can occur throughout the year, but occurs most frequently during the winter-spring transition, when increased cyclonic activity enables the pollution to be transferred along warm conveyor belts into the vertically stratified Arctic atmosphere (Shaw, 1995; Stohl, 2001; Fuelberg et al., 2003; Scheuer et al., 2003; Quinn et al., 2007). These Arctic haze layers can persist for weeks and have been attributed to both industrial sources (Law and Stohl, 2007) and biomass burning (Stohl et al., 2006, 2007; Quinn et al., 2008; Warneke et al., 2009, 2010). The frequency and intensity of transport emissions, particularly from Asia, may also be modulated by large scale climate variability; for example, strong El Niño conditions are known to enhance the transport of pollutants into the Arctic (Fisher et al., 2010).

Boreal forest fires have also become increasingly recognized as a dominant source of transported aerosol to the Arctic, especially during the active summer fire season (Warneke et al., 2009, 2010). These emissions are expected to increase in the future, as fire occurrence and intensity increase with a warming climate (Reid et al., 2005). The emissions and properties of the smoke can be highly variable depending significantly on the type of biomass burned, but are known to contribute substantially to cloud condensation nuclei (CCN) (e.g., Reid et al., 2005; Pratt et al., 2011; Engelhart et al., 2012) and black and light-absorbing carbon (Matsui et al.,
2011). This variability leads to increased uncertainty in predicting the direct and indirect impacts of biomass burning emissions on Arctic climate. Finally, particles can be directly emitted into the Arctic atmosphere, arising from a variety of natural or anthropogenic sources. Natural emissions of organic-rich materials, microgels, and dimethyl sulfide (DMS) have been observed above the open ocean surface or open leads in pack ice (Leaitch et al., 1983; Charlson et al., 1987; Leaitch et al., 1994; Leck and Persson, 1996; Leck et al., 2002; Martin et al., 2011; Orellana et al., 2011), and additional natural sources (such as secondary organic aerosol production from oxidation of biogenic volatile organic compounds) can arise from the boreal forest ecosystems (Spracklen et al., 2008; Slowik et al., 2010). As sea ice coverage decreases and boreal forests expand into the more temperate climate zones (Elmendorf et al., 2012), these emissions are suspected to play an increasingly important, yet uncertain, role in Arctic climate. Industrial activities can also directly contribute aerosol into the Arctic environment, and with oil exploration and transportation through open waters in these regions increasing, it is also expected that these emissions will become increasingly important in the future (McLinden et al., 2012).

The existing in-situ measurements of Arctic aerosol have been conducted through various ground-based, ship and airborne observation platforms to capture both the temporal (ground studies) and spatial (airborne/ship studies) variability of the aerosol (e.g., Leck et al., 2002; Kammermann et al., 2010; Martin et al., 2011; Brock et al., 2011; Moore et al., 2011; Heintzenberg and Leck, 2012). However, comprehensive in-situ measurements of the Arctic are limited, primarily because of the remoteness and harsh conditions that can make long term sampling challenging. Observed CCN number concentrations have historically been less than $100 \mathrm{~cm}^{-3}$ in the pristine Arctic background air, but can reach values as high as $10^{3} \mathrm{~cm}^{-3}$ in haze layers indicative of long-range transport of pollutants (Leaitch et al., 1983; Moore et al., 2011 , and references therein), or as low as $1 \mathrm{~cm}^{-3}$ (Mauritsen et al., 2011). The large variability in Arctic CCN number concentration is a result of varying particle sources and chemical composition throughout the years, as well as efficient loss mechanisms (Browse et al., 2012). The resulting seasonality in aerosol mass, composition, and CCN is an important effect that models still have difficulty accurately representing (e.g., Shindell et al., 2008).

While observations of aerosol and CCN in the Arctic are sparse and difficult to obtain, studying their impacts on Arctic climate through models can be even more challenging. It is well known that increased CCN concentrations can lead to the production of more numerous and smaller cloud drops, which can result in optically thicker clouds that tend to reflect more incoming solar radiation back to space (Twomey, 1977). However, since the Arctic is generally characterized by an already highly reflective surface of ice and snow, the surface cooling effect from increased cloud reflectivity is 
thought to be small (Tietze et al., 2011). A distinctly different, and perhaps more significant, indirect effect from increased CCN has recently been proposed for thin Arctic clouds, where increased aerosol has been shown to increase the longwave emissivity of the cloud, thereby warming the surface (Garrett and Zhao, 2006; Lubin and Vogelmann, 2006; Alterskjær et al., 2010). Furthermore, it has been suggested that $\mathrm{CCN}$ may be important for modulating ice formation processes in mixed-phase clouds, leading to greater cloud lifetime, increased cloud emissivity, and reduced precipitation (Lance et al., 2011). A lack of understanding of ice nuclei (IN) and ice initiation processes may also be one of the reasons regional and global climate models are not able to accurately reproduce Arctic clouds and the Arctic radiation budget (Prenni et al., 2007).

An important challenge for aerosol-cloud interaction studies is the treatment of complex aerosol chemical properties in atmospheric models without adding significant computational burden or uncertainty. Many recent studies have shown that, for CCN activity, the influence of aerosol composition can be efficiently represented by a single hygroscopicity parameter, $\kappa$, which simply expresses the affinity of a given aerosol particle for water (Petters and Kreidenweis, 2007). The $\kappa$ for atmospheric particles can range anywhere from $\sim 0$ for insoluble, wettable species to 1.3 for sodium chloride (Petters and Kreidenweis, 2007). However, some insoluble particles, like dust and volcanic ash, can exhibit significant hydrophilicity from the presence of clays and surface porosity, such that these species can activate at much lower supersaturations than expected for $\kappa=0$ (Kumar et al., 2011; Lathem et al., 2011). The availability of existing observational data is not sufficient to effectively constrain the $\kappa$ for Arctic aerosol, particularly its regional and seasonal variability. It has been suggested by Andreae and Rosenfeld (2008) that the effective $\kappa$ for continental aerosol is $0.3 \pm 0.1$, consistent with global modeling studies (e.g., Pringle et al., 2010). However, neither study provides estimates of $\kappa$ for the Arctic environments and Moore et al. (2012) show that the sensitivity of $\mathrm{CCN}$ to aerosol composition and number in the Arctic is unusually high, where cloud droplet number concentration uncertainty to $\mathrm{CCN}$ prediction errors can exceed $70 \%$. CCN prediction errors in global climate models are determined by computing a CCN spectrum based on a known or predicted aerosol number and chemical size distribution. Errors in the latter introduce a prediction uncertainty in the $\mathrm{CCN}$ spectrum which leads to uncertainty in cloud droplet number concentration and the indirect effect. The high sensitivity identified by Moore et al. (2012) underscores the need to understand and quantify the regional and seasonal changes in Arctic $\kappa$, which can be one of the primary drivers of $\mathrm{CCN}$ prediction uncertainty.

There is overwhelming evidence that organics can represent more than $50 \%$ of the total aerosol mass in the Arctic (Quinn et al., 2009; Shaw et al., 2010; Frossard et al., 2011; Moore et al., 2011). Since a significant fraction of or- ganics can also be hygroscopic (Hennigan et al., 2008; Fu et al., 2009; Duplissy et al., 2011), an understanding of the particle $\kappa$ and $\mathrm{CCN}$ activity requires understanding the hygroscopicity contribution from organics, $\kappa_{\text {org }}$. The value of $\kappa_{\text {org }}$ can range from zero for insoluble species to $\sim 0.3$ for the water-soluble carbon extracted from secondary organic aerosol (SOA) and biomass burning aerosols (Wang et al., 2010; Padró et al., 2010; Asa-Awuku et al., 2010). Several recent studies have confirmed that $\kappa_{\text {org }}$ is an important variable for understanding and predicting the $\mathrm{CCN}$ activity of Arctic aerosol. These studies account for $\kappa_{\text {org }}$ in CCN predictions by making various assumptions about the relative fractions of insoluble and soluble organic species, as well as varying the $\kappa_{\text {org }}$ as a fitting parameter until ideal closure is achieved, (e.g., Bougiatioti et al., 2009, 2011; Moore et al., 2011; Dusek et al., 2011; Martin et al., 2011). For example, Moore et al. (2011) found the lowest CCN prediction errors $(<20 \%)$ for Alaskan springtime Arctic aerosol when the aerosol population was assumed to be an external mixture with moderately hygroscopic organics $\left(\kappa_{\text {org }}=0.11\right)$. On the other hand, Martin et al. (2011) studied Arctic aerosol over the summertime pack ice $\left(>85^{\circ} \mathrm{N}\right)$ and found low CCN prediction errors by assuming the aerosol to be internally mixed with primarily insoluble organics $\left(\kappa_{\mathrm{org}}=0.02\right)$. The large differences in $\kappa_{\text {org }}$ between the two studies and differences in assumed mixing state highlight potentially large regional or seasonal variability in Arctic aerosol properties and motivate a need for a more comprehensive understanding of the factors leading to this variability.

Determination of $\kappa_{\text {org }}$ is far from trivial, owing to the complexity of the organic aerosol fraction and its tendency to evolve with atmospheric oxidative processing and aerosol aging (Jimenez et al., 2009). Numerous studies have sought to reduce this complexity by estimating $\kappa_{\text {org }}$ based upon other easily measured aerosol parameters, without having to explicitly know the detailed organic speciation. One method has been to parameterize the $\kappa_{\text {org }}$ with respect to the fraction of water-soluble organic carbon (WSOC) or water-soluble organic matter (WSOM) (Padró et al., 2010; Engelhart et al., 2011; Asa-Awuku et al., 2011), as it is the soluble organics that are most hygroscopic. These studies suggest that $\kappa_{\text {org }}=(0.25 \pm 0.05) \varepsilon_{\mathrm{WSOM}}$, where $\varepsilon_{\mathrm{WSOM}}$ is the volume fraction of total organic aerosol which is water-soluble. Another method has been to correlate $\kappa_{\text {org }}$ with the $\mathrm{O}: \mathrm{C}$ (or $f_{44}$ as a surrogate of $\mathrm{O}: \mathrm{C}$ ) determined from an aerosol mass spectrometer (AMS) (Jimenez et al., 2009; Chang et al., 2010; Duplissy et al., 2011; Lambe et al., 2011), where the $\kappa_{\text {org }}$ is expected to increase with the $\mathrm{O}: \mathrm{C}$, which is proportional to the mass fraction of oxygenated functional groups that should increase the solubility of the organic species. In previous laboratory and chamber studies, the SOA $\kappa$ has been observed to correlate strongly with the AMS O: C ratio (or $f_{44}$ ) (Jimenez et al., 2009; Duplissy et al., 2011). These studies suggest that atmospheric photochemical oxidation may increase the overall SOA or $\kappa_{\text {org }}$ as a result of increased aerosol 
oxygenation and reduced organic aerosol volatility. Chang et al. (2010) report a linear relationship between the $\kappa_{\text {org }}$ and $\mathrm{O}: \mathrm{C}$ ratio for organic aerosol in rural Egbert Ontario, Canada, such that $\kappa_{\text {org }}=(0.29 \pm 0.05)(\mathrm{O}: \mathrm{C})$, although they stress the need for further studies to characterize if this relationship holds for a wider range of $\mathrm{O}: \mathrm{C}$ and aerosol types and locations. Engelhart et al. (2012) report an increasing trend in total primary aerosol $\kappa$ with increasing $f_{44}$ for the aging of fresh biomass burning emissions in a smog chamber. These relationships between $\mathrm{O}: \mathrm{C}$ and $\kappa_{\text {org }}$ do not necessarily imply $\mathrm{O}: \mathrm{C}$ controls $\kappa_{\text {org }}$, but rather that $\mathrm{O}: \mathrm{C}$ is a proxy for aerosol molecular properties, such as molar volume and solubility, that control $\kappa_{\text {org }}$. Very few studies to date have all of the available data to fully link measurements of WSOC, $\mathrm{O}: \mathrm{C}$ and $\kappa_{\text {org }}$ with changes in CCN activity (e.g., Suda et al., 2012).

In this study, we present observations and provide model parameters for the physical, chemical, and hygroscopic properties of summertime Arctic aerosol from dominant source components (including Arctic background, boreal forests, biomass burning influences, and anthropogenic industrial emissions). These measurements were collected during 2008 as part of the NASA ARCTAS (Arctic Research of the Composition of the Troposphere from Aircraft and Satellites) campaign and cover the summertime Arctic, from $50-85^{\circ} \mathrm{N}$ and $40-130^{\circ} \mathrm{W}$. The measured physical and chemical properties of the aerosol are used to constrain the aerosol hygroscopicity. An aerosol-CCN closure study for each source is presented, using assumptions and simplifications most utilized by global climate models (e.g., Bauer et al., 2010; Mann et al., 2010; Meskhidze et al., 2011; Zhang et al., 2012). Additionally, we investigate the aging of the aerosol, specifically for biomass burning, by exploring the relationship between particle $\kappa$, oxidation state, and the fraction of water-soluble organic matter. Finally, we explore the importance of supersaturation depletion in determining $\kappa$ and the $\mathrm{CCN}$ spectra. As first shown by Lathem and Nenes (2011), high concentrations of $\mathrm{CCN}\left(>5 \times 10^{3} \mathrm{~cm}^{-3}\right)$ can significantly deplete the calibrated instrument supersaturation, and the resulting biases in $\mathrm{CCN}$ closure and inferred $\kappa$ this depletion causes are investigated and a method for correcting these biases is introduced.

\section{Experimental measurements}

\subsection{Aircraft measurements}

The 2008 ARCTAS mission was in support of the 4th International Polar Year (IPY) collaborative effort POLARCAT (Polar Study using Aircraft, Remote Sensing, Surface Measurements and Models, of Climate, Chemistry, Aerosols, and Transport). An extensive overview and description of the mission is given by Jacob et al. (2010) and the accompanying detailed meteorological overview and modeled air mass back trajectories is provided by Fuelberg et al. (2010). The results presented here represent nine flights from the summertime ARCTAS-B deployment phase on the NASA Dryden Flight Research Center DC-8 aircraft platform, which took place from 26 June to 14 July 2008. Flights were based out of Cold Lake, Alberta, Canada $\left(54^{\circ} \mathrm{N}, 110^{\circ} \mathrm{W}\right)$ and included transits to and from Thule, Greenland $\left(77^{\circ} \mathrm{N}, 69^{\circ} \mathrm{W}\right)$, and, a local flight out of Thule over Summit, Greenland $\left(73^{\circ} \mathrm{N}, 39^{\circ} \mathrm{W}\right)$. The primary objective of ARCTAS-B was to investigate and characterize fresh boreal forest fire emissions in Canada, as well as their evolution and transport into the Arctic environment. A majority of the aerosol sampling occurred within the boundary layer and lower free troposphere, with fresh biomass burning emissions sampled primarily in the boundary layer within a few hours after emission. In addition to the fresh boreal fire emissions, several additional environments and sources were characterized, including boreal forest and Arctic backgrounds, transported Siberian biomass smoke, and direct sampling of industrial pollution from Canadian oil sands operations at Fort McMurray. A map of the flight tracks, colored by the measured air mass type, is shown in Fig. 1, with details on the source identification methods provided in Sect. 3.3.

Aerosol properties (number density, size distributions, optical properties, and $\mathrm{CCN}$ ) were measured aboard the DC-8 as part of the NASA Langley Aerosol Research Group Experiments (LARGE), with instrumentation mounted inside the cabin and optimized for reduced pressure (Thornhill et al., 2008; Chen et al., 2011). Isokinetic flow was maintained through the aerosol sampling inlet by determining the ideal flow based on real-time measurements of air speed, static pressure, and temperature, which minimizes inertial sampling biases (Chen et al., 2011). The University of Hawaii solid diffuser inlet (UH-SDI) was window mounted at the forward right section of the aircraft ahead of all engines and has a $50 \%$ sampling efficiency at $5 \mu \mathrm{m}$ dry aerodynamic diameter (Clarke et al., 2007; McNaughton et al., 2007). CCN sampling transmission efficiency was determined from field calibration experiments to be $>90 \%$ for particles larger than $30 \mathrm{~nm}$.

\subsection{Submicron particle number density and size distribution measurements}

Particle number density $(\mathrm{CN})$ was measured with several TSI condensation particle counters (CPC), including a TSI CPC-3010 and CPC-3772 to measure total CN greater than $10 \mathrm{~nm}$, and a TSI CPC-3025 (ultrafine CPC) to measure total $\mathrm{CN}$ greater than $3 \mathrm{~nm}$. Dry aerosol size distributions were measured independently via a Droplet Measurement Technologies Ultra High Sensitivity Aerosol Spectrometer (DMTUHSAS; Cai et al., 2008) and a customized Scanning Mobility Particle Sizer (SMPS) system. The DMT-UHSAS provides aerosol size distributions for the $0.07-1 \mu \mathrm{m}$ dry diameter range at a time resolution of $1 \mathrm{~Hz}$ and was calibrated 


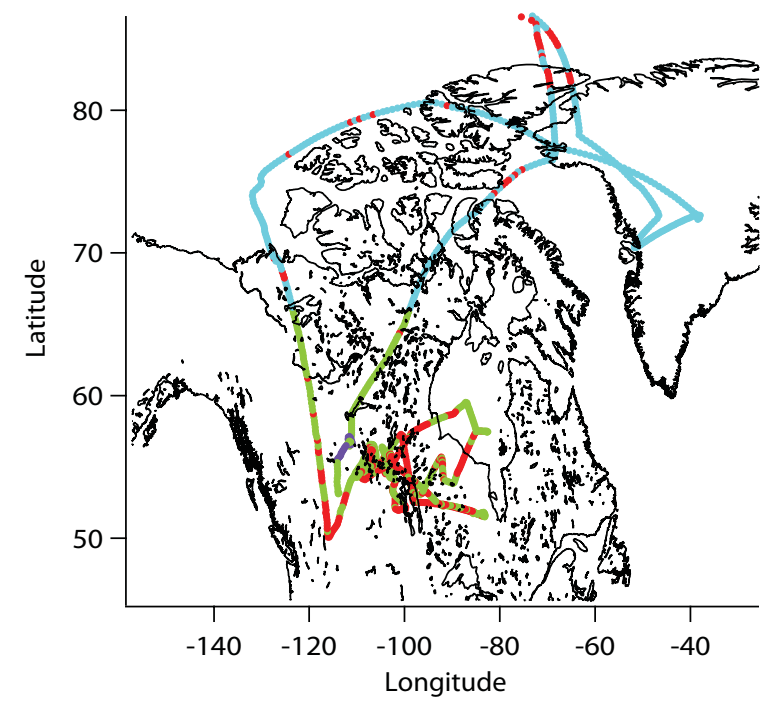

Fig. 1. Aircraft flight trajectories for the research flights of ARCTAS-B on the NASA DC-8, colored by air mass source type. Red colors denote biomass burning, green colors denote boreal forest background, blue colors denote Arctic background, and purple colors denote anthropogenic industrial pollution.

in the field using polystyrene latex spheres (PSL). Error in the UHSAS PSL calibration due to the refractive index difference between PSL and ambient particles was investigated by comparing with size calibrations using ammonium sulfate particles. A UHSAS sizing bias from using the PSL calibration was found to not be important $(<8 \%)$ for the dry particle size range investigated here. Due to operating issues at low pressure, only DMT-UHSAS data below $\sim 2130 \mathrm{~m}$ flight altitude was used in data analysis. The custom SMPS system consisted of a TSI Long Differential Mobility Analyzer (DMA) column, sheath and aerosol flow control, and a CPC3010. The SMPS system provided size distributions over the dry diameter range of 8-250 nm with a scan time of $105 \mathrm{~s}$. SMPS sizing was calibrated with PSL and reported mobility diameters corrected for changes in ambient temperature and pressure. SMPS concentrations were also corrected for multiple charge distributions at ambient pressure and for diffusion losses in the SMPS and CPC systems.

For altitudes lower than $2130 \mathrm{~m}$, the UHSAS data was averaged over the SMPS scan time, and both distributions were merged to provide a full size distribution from $8 \mathrm{~nm}$ to $1 \mu \mathrm{m}$ diameter. The merged distributions for every flight were then visually inspected to ensure the diameter bins were properly merged and that the concentration in the region of size overlap between the two distributions agreed to within $15 \%$. The integrated counts from the merged particle size distributions were then scaled to match the total $\mathrm{CN}$ from the CPC-3010 (although the merged SMPS-UHSAS distributions agreed with the CPC-3010 counts to within $25 \%$ ). There is inherent variability associated with aircraft measurements; to ensure that this variability did not induce biases, the variability in CN over a given SMPS scan was a metric to determine if the SMPS scan was representative of a constant or changing environment. If the $\mathrm{CN}$ standard deviation over an SMPS scan time exceeded $50 \%$ of the average $\mathrm{CN}$ reported for that scan, then the scan was not included in the data analysis. This type of SMPS filtering was most important for sampling biomass burning plumes, where in a given scan time, both background air and a plume could be sampled within a single $105 \mathrm{~s}$ scan. To ensure representative sampling of environments, only scans corresponding to a single air mass type (e.g., only background or only plume) were included in the various source type analysis.

\subsection{Submicron particle chemical composition measurements}

Measurements of the non-refractory submicron aerosol composition were made with an Aerodyne high-resolution timeof-flight aerosol mass spectrometer (HR-ToF-AMS, DeCarlo et al., 2006) with a pressure controlled inlet (Bahreini et al., 2008), as described in Cubison et al. (2011). Bulk aerosol mass loadings for sulfate, nitrate, ammonium and organic aerosol components were calculated from the mass spectra and recorded at $12 \mathrm{~s}$ data intervals, with estimated relative uncertainties on the order of $34 \%$ and $38 \%$ for inorganic and organic components, respectively, which includes uncertainty in particle collection efficiency due to particle bounce (Huffman et al., 2005; Bahreini et al., 2009; Middlebrook et al., 2012). For the purpose of CCN analyses, the organic aerosol mass spectra were further utilized to provide information on the oxygenation state of the aerosol, via the $\mathrm{O}: \mathrm{C}$ ratio, which can be a proxy for both particle aging and hygroscopicity (Jimenez et al., 2009; Duplissy et al., 2011). A small fraction of the nominally inorganic AMS species could be due to organosulfates, organonitrates, or amines (Farmer et al., 2010).

Submicron water-soluble organic carbon (WSOC) measurements were made with a particle-into-liquid-sampler (PILS) coupled to a total organic carbon (TOC) analyzer (Sullivan et al., 2004, 2006). The PILS-WSOC provided three second integrated measurements of the concentration of WSOC. A WSOC to organic carbon (OC) ratio, WSOC/OC, is calculated by comparing the amount of WSOC measured by the PILS to the amount of organic matter (OM) measured by the AMS. For this study, WSOC is converted to WSOM by multiplying by an OM/OC ratio of 1.6. A OM/OC ratio of 1.6 is consistent with moderately aged organics with an $\mathrm{O}: \mathrm{C}$ ratio of $\sim 0.4$ (Aiken et al., 2008) and biomass smoke particles (Hand et al., 2010). However, it should be noted that there is considerable variability in reported $\mathrm{OM} / \mathrm{OC}$ ratios for organic compounds depending on the relative contribution of primary and secondary organic aerosol sources, with reported values ranging from 1.2-2.4 (Turpin and Lim, 2001; Russell, 2003; Aiken et al., 2008). To account for this uncertainty in the $\mathrm{OM} / \mathrm{OC}$ ratio, sensitivity studies were performed 
Table 1. Summary of aerosol microphysical and chemical properties for each source type. Median size $\left(D_{\mathrm{p}}\right.$, nm) and standard deviation $\left(\sigma_{\mathrm{g}}\right)$ are from lognormal fits to the merged UHSAS and SMPS distributions. Total volume of Organic Carbon (OC) and the Water-soluble Organic Matter (WSOM) fraction of the OC are percentages calculated from total HR-ToF-AMS and PILS-WSOC mass loadings (Sect. 2.3). Inferred particle hygroscopicity, $\kappa$, is from measured $\mathrm{CCN}$ and size distributions while calculated $\kappa$ is from AMS and WSOM composition (Sect. 3.1). Median CN and CCN concentrations are reported in $\mathrm{cm}^{-3}$ at STP. CCN and Activation Ratio (AR, CCN/CN) are reported at $0.55 \%$ instrument supersaturation. Biomass burning is abbreviated as BB.

\begin{tabular}{|c|c|c|c|c|c|c|c|c|c|c|c|}
\hline Air Mass Type & $D_{\mathrm{p} 1}$ & $\sigma_{\mathrm{g} 1}$ & $D_{\mathrm{p} 2}$ & $\sigma_{\mathrm{g} 2}$ & $\begin{array}{r}\text { Total } \\
\text { OC }\end{array}$ & $\begin{array}{l}\text { WSOM } \\
\text { Fraction }\end{array}$ & $\begin{array}{r}\kappa \\
\text { Inferred }\end{array}$ & $\begin{array}{r}\kappa \\
\text { Calculated }\end{array}$ & $\mathrm{CN}$ & $\mathrm{CCN}$ & $\mathrm{AR}$ \\
\hline Fresh BB & $146 \pm 2$ & $1.55 \pm 0.02$ & - & - & $93 \pm 4$ & $57 \pm 19$ & $0.18 \pm 0.16$ & $0.11 \pm 0.04$ & 7832 & 7778 & 0.89 \\
\hline Aged BB & $48 \pm 1$ & $2.16 \pm 0.08$ & - & - & $78 \pm 14$ & $80 \pm 16$ & $0.18 \pm 0.10$ & $0.24 \pm 0.10$ & 709 & 217 & 0.35 \\
\hline Arctic & $84 \pm 2$ & $2.05 \pm 0.04$ & - & - & $66 \pm 22$ & $87 \pm 25$ & $0.32 \pm 0.21$ & $0.34 \pm 0.17$ & 514 & 247 & 0.52 \\
\hline Boreal Forest & $31 \pm 1$ & $1.37 \pm 0.04$ & $107 \pm 3$ & $1.75 \pm 0.04$ & $94 \pm 2$ & $91 \pm 22$ & $0.17 \pm 0.14$ & $0.16 \pm 0.03$ & 651 & 319 & 0.55 \\
\hline Industrial Pollution & $52 \pm 1$ & $1.45 \pm 0.01$ & $154 \pm 2$ & $2.19 \pm 1.3$ & $84 \pm 3$ & $95 \pm 10$ & $0.08 \pm 0.01$ & $0.22 \pm 0.02$ & 2229 & 341 & 0.15 \\
\hline
\end{tabular}

using OM/OC ratios of 1.6 and 2.2. It was found that increasing the $\mathrm{OM} / \mathrm{OC}$ ratio from 1.6 to 2.2 would lead to a $15 \%$ maximum increase in the reported WSOM fraction (Table 1). This increase in the WSOM fraction would increase the reported CCN closure errors (Table 2) by an average of $4 \%$ and increase the calculated $\kappa$ by an average of 0.02 (Sect. 4.2), which are both within the reported variability.

\subsection{Gas phase measurements}

Jacob et al. (2010) provide a complete list of all gas-phase measurements made aboard the NASA DC- 8 during ARCTAS. Select measurements were used in this study to classify air masses by source type, being carbon monoxide (CO), carbon dioxide $\left(\mathrm{CO}_{2}\right)$, acetonitrile $\left(\mathrm{CH}_{3} \mathrm{CN}\right)$, methane $\left(\mathrm{CH}_{4}\right)$, sulfur dioxide $\left(\mathrm{SO}_{2}\right)$, nitrogen oxides $\left(\mathrm{NO}_{\mathrm{x}}=\mathrm{NO}+\mathrm{NO}_{2}\right)$, and oxidized nitrogen $\left(\mathrm{NO}_{\mathrm{y}}\right) . \mathrm{CH}_{3} \mathrm{CN}$ and $\mathrm{CO}$ were used as biomass burning and combustion tracers, whereas $\mathrm{SO}_{2}$ and $\mathrm{NO}_{\mathrm{x}} / \mathrm{NO}_{\mathrm{y}}$ were used to isolate anthropogenic industrial sources. The full details of how each gas phase species was used in the source type analysis is provided in Sect. 3.3.

\subsection{CCN measurements}

CCN measurements were made with a Droplet Measurement Technologies (DMT) continuous-flow, streamwise thermalgradient $\mathrm{CCN}$ counter (hereafter referred to as CCNC; Robert and Nenes, 2005; Lance et al., 2006; Lathem and Nenes, 2011; Raatikainen et al., 2012). The CCNC was located within the LARGE instrument rack, sharing sampling lines with the SMPS and CPC-3772, such that the size distribution and total number concentration of the aerosol could be directly related to the $\mathrm{CCN}$ measurements. The CCNC generates a controlled and precise supersaturation within a cylindrical column, which is continuously wet with water and experiences a linear temperature gradient generated by applying a temperature difference $(\Delta T)$ between the column top and bottom. As particles flow through the centerline of the column and are exposed to this supersaturation, they can uptake the water vapor and activate to form droplets, depen- dent upon their size and chemical composition. The CCNC measures the total number density and size distribution of activated droplets in the diameter size range of $1-10 \mu \mathrm{m}$, with a reporting frequency of $1 \mathrm{~Hz}$.

During ARCTAS, the CCNC was operated at a constant flow rate of $0.5 \mathrm{~L} \mathrm{~min}^{-1}$ and a constant pressure of $450 \mathrm{hPa}$. The pressure was maintained by use of a flow orifice and active pressure control system, which compensates for changes in ambient pressure due to changes in aircraft altitude. High altitude sampling, in which the ambient pressure dropped below $450 \mathrm{hPa}$, was not included in the analysis presented herein, because pressure fluctuations affect instrument supersaturation. At a constant flow rate and pressure, the instrument supersaturation scales linearly with $\Delta T$ (Robert and Nenes, 2005), and so the applied $\Delta T$ was increased in discrete steps between 5.8 and $12.3 \mathrm{~K}$ to provide a calibrated supersaturation range of $0.20-0.57 \%$. Data collected during instrument transient operation, during change in instrument supersaturation, or when flow or instrument pressure fluctuated by more than $0.5 \%$ about the mean were excluded from analysis (Asa-Awuku et al., 2011). The instrument supersaturation was calibrated before, during and after the field experiment with size-selected ammonium sulfate particles via Scanning Mobility CCN Analysis (SMCA) following the procedures of Moore et al. (2010). The relative error in calibrated supersaturation for the ARCTAS experiment is reported to be $0.05 \%$ (absolute). The total uncertainty in reported $\mathrm{CCN}$ number concentrations derived from counting statistics and instrument operating parameter variability (temperature, pressure, flow) is $7-16 \%$ for $\mathrm{CCN}$ concentrations above $100 \mathrm{~cm}^{-3}$ STP (Moore et al., 2011). The calibrated instrument supersaturation has been corrected for supersaturation depletion, which becomes important for $\mathrm{CCN}$ concentrations above $5 \times 10^{3} \mathrm{~cm}^{-3}$ (Lathem and Nenes, 2011). The methodology for the supersaturation depletion correction is presented in Sect. 3.2. 
Table 2. Summary of CCN closure errors (\%) for the three closure scenarios tested: (1) internally mixed aerosol with organics assumed completely insoluble with $\kappa_{\text {org }}=0$, (2) internally mixed aerosol with hygroscopicity of organics parameterized by $\kappa_{\text {org }}=0.12 \varepsilon_{\text {WSOM }}$ and (3) externally mixed aerosol with hygroscopicity of organics parameterized by $\kappa_{\mathrm{org}}=0.12 \varepsilon$ WSOM. Supersaturation and Activation Ratio $(\mathrm{CCN} / \mathrm{CN})$ are denoted as $s$ and AR, respectively.

\begin{tabular}{|c|c|c|c|c|c|}
\hline \multirow[b]{2}{*}{ Air Mass Type } & \multirow{2}{*}{\multicolumn{2}{|c|}{ AR }} & \multicolumn{2}{|c|}{ Internal Mixture } & \multirow{2}{*}{$\begin{array}{r}\text { External Mixture } \\
\text { WSOM }\end{array}$} \\
\hline & & & WSOM & OC Insoluble & \\
\hline \multicolumn{6}{|c|}{ Fresh Biomass Burning } \\
\hline$s=0.26 \pm 0.05$ & $(\%)$ & $0.57 \pm 0.17$ & $25 \pm 38$ & $-35 \pm 18$ & $12 \pm 30$ \\
\hline$s=0.37 \pm 0.05$ & $(\%)$ & $0.87 \pm 0.15$ & $-4 \pm 24$ & $-46 \pm 19$ & $-14 \pm 26$ \\
\hline$s=0.48 \pm 0.05$ & $(\%)$ & $0.90 \pm 0.15$ & $-17 \pm 11$ & $-51 \pm 12$ & $-24 \pm 12$ \\
\hline \multicolumn{6}{|c|}{ Aged Biomass Burning } \\
\hline$s=0.23 \pm 0.05$ & $(\%)$ & $0.45 \pm 0.14$ & $30 \pm 19$ & $-20 \pm 9$ & $20 \pm 15$ \\
\hline$s=0.53 \pm 0.05$ & $(\%)$ & $0.38 \pm 0.15$ & $16 \pm 11$ & $-17 \pm 11$ & $2 \pm 7$ \\
\hline \multicolumn{6}{|l|}{ Boreal Forest } \\
\hline$s=0.34 \pm 0.05$ & $(\%)$ & $0.32 \pm 0.14$ & $31 \pm 11$ & $-41 \pm 9$ & $24 \pm 15$ \\
\hline$s=0.42 \pm 0.05$ & $(\%)$ & $0.46 \pm 0.18$ & $19 \pm 20$ & $-45 \pm 6$ & $13 \pm 17$ \\
\hline$s=0.55 \pm 0.05$ & $(\%)$ & $0.60 \pm 0.17$ & $-2 \pm 16$ & $-48 \pm 9$ & $-10 \pm 17$ \\
\hline \multicolumn{6}{|l|}{ Arctic } \\
\hline$s=0.42 \pm 0.05$ & $(\%)$ & $0.33 \pm 0.15$ & $16 \pm 23$ & $-19 \pm 17$ & $0 \pm 25$ \\
\hline$s=0.57 \pm 0.05$ & $(\%)$ & $0.51 \pm 0.17$ & $8 \pm 18$ & $-24 \pm 15$ & $-2 \pm 15$ \\
\hline \multicolumn{6}{|c|}{ Industrial Pollution } \\
\hline$s=0.42 \pm 0.05$ & $(\%)$ & $0.08 \pm 0.04$ & $195 \pm 67$ & $14 \pm 7$ & $153 \pm 37$ \\
\hline$s=0.57 \pm 0.05$ & $(\%)$ & $0.15 \pm 0.02$ & $158 \pm 57$ & $18 \pm 19$ & $105 \pm 39$ \\
\hline
\end{tabular}

\section{Methods}

\subsection{Inferring particle hygroscopicity}

The concentration of $\mathrm{CCN}$ represents the fraction of aerosol particles that form droplets in cloudy air parcels and depends on aerosol dry size, chemical composition, and ambient water vapor supersaturation. Quantitatively, the level of water vapor above which a particle acts as a CCN is given by Köhler theory (Köhler, 1936). Expressed in terms of critical supersaturation, $s_{\mathrm{c}}$ (where $s_{\mathrm{c}}=\mathrm{RH}-1$, and $\mathrm{RH}$ is the fractional relative humidity), theory gives:

$s_{\mathrm{c}}=\left[\frac{4 \rho_{\mathrm{w}} M_{\mathrm{s}}}{\rho_{\mathrm{s}} M_{\mathrm{w}} v_{\mathrm{i}} D_{\mathrm{p}}^{3}}\left(\frac{4 \sigma M_{\mathrm{w}}}{3 R T \rho_{\mathrm{w}}}\right)^{3}\right]^{1 / 2}$

where $\rho_{\mathrm{w}}$ is the density of water, $\rho_{\mathrm{s}}$ the density of solute, $M_{\mathrm{w}}$ the molar mass of water, $M_{\mathrm{S}}$ the molar mass of solute, $v_{\mathrm{i}}$ the effective van't Hoff dissociation factor, $D_{\mathrm{p}}$ the dry particle diameter, $R$ the gas constant, $T$ the absolute temperature, and $\sigma$ the surface tension of the solution droplet. Here, the standard convention of assuming the surface tension of the solution drop is equal to that of pure water $\left(\sigma=\sigma_{\mathrm{w}}\right)$ is used, which is a good approximation for dilute droplets unless they contain considerable amounts of strong surfactants.
Petters and Kreidenweis (2007) suggested replacing the term $\frac{\rho_{\mathrm{s}} M_{\mathrm{w}} v_{i}}{\rho_{\mathrm{w}} M_{\mathrm{s}}}$ with an adjustable parameter, $\kappa$, termed the hygroscopicity parameter. $\kappa$ expresses the affinity of a material for water and is a simple way to parameterize the solute term of Köhler theory, such that Eq. (1) becomes:

$s_{\mathrm{c}}=\left[\frac{4}{\kappa D_{\mathrm{p}}^{3}}\left(\frac{4 \sigma_{\mathrm{w}} M_{\mathrm{w}}}{3 R T \rho_{\mathrm{w}}}\right)^{3}\right]^{1 / 2}$

If the particle is composed of many compounds, the total particle $\kappa$ is calculated as the volume fraction weighted average $\kappa$ of the individual aerosol components:

$\kappa=\sum_{j} \varepsilon_{j} \kappa_{j}$

where $\kappa_{j}$ and $\varepsilon_{j}$ represents the $\kappa$ and volume fraction of chemical species $j$, respectively. This approach treats the particles as internal mixtures, where all particles have identical chemical composition and $\kappa$ is the same for all particle sizes. In this study, the average composition is derived from bulk submicron mass concentrations provided by the HRToF-AMS and PILS-WSOC. Composition is approximated as a mixture of ammonium sulfate, ammonium nitrate, ammonium bisulfate, sulfuric acid, water-soluble organics, and water-insoluble inorganics (taken as the difference between 
total OA and WSOM). BC is neglected from this analysis due to its low mass fraction (less than $4 \%$ by volume) (e.g., Kondo et al., 2011). The inorganic fraction of the aerosol is partitioned between neutral and acidic sulfate species using the molar ratio of ammonium ions to sulfate and nitrate ions, $R_{\mathrm{SO}_{4}}$, and mass balance following the procedures of Nenes et al. (1998) and Moore et al. (2011). For $R_{\mathrm{SO}_{4}}>2$, the sulfate is present as ammonium sulfate, while for $1<R_{\mathrm{SO}_{4}}<2$, the sulfate is present as a mixture of ammonium sulfate and ammonium bisulfate. At $R_{\mathrm{SO}_{4}}<1$, the sulfate is present as a mixture of ammonium bisulfate and sulfuric acid. Mass fractions of each constituent are converted into volume fractions (required by Eq. 3) using the known densities of the inorganic constituents and assuming an organic density of $1400 \mathrm{~kg} \mathrm{~m}^{-3}$ (Reid et al., 2005; King et al., 2007; Moore et al., 2011; Kuwata et al., 2012). Apart from $\varepsilon_{\text {org }}$, Eq. (3) also requires knowledge of the $\kappa$ of the organic component, $\kappa_{\text {org }}$. A number of approaches are tested to estimate and understand the evolution of $\kappa_{\text {org }}$ (Sects. 4.3 and 4.4).

Alternatively, the bulk aerosol $\kappa$ can be inferred from measurements of $\mathrm{CCN}$ activity and particle size distributions (e.g., Jurányi et al., 2010; Moore et al., 2011; Bougiatioti et al., 2009). Equation (2) allows a direct inference of the volume averaged particle $\kappa$, provided the supersaturation and dry particle size are known, and assuming the particle chemical composition is internally mixed. First, the critical diameter for activation, $D_{\mathrm{pc}}$, must be determined by integrating the particle size distribution, starting from the largest size bin, until the concentration matches the measured $\mathrm{CCN}$ concentration at a given supersaturation, using Eq. (4):

$N_{\mathrm{CCN}}=\int_{D_{\mathrm{pc}}}^{\infty} n_{\mathrm{CN}} \mathrm{d} D_{\mathrm{p}}$

where $N_{\mathrm{CCN}}$ is the measured $\mathrm{CCN}$ number concentration and $n_{\mathrm{CN}}$ is the particle size distribution function from the SMPS and UHSAS merged distributions. The $D_{\mathrm{pc}}$ can then be substituted into Eq. (2) to determine $\kappa$, at a set instrument supersaturation.

\subsection{Supersaturation depletion correction}

Lathem and Nenes (2011) show that the calibrated CCNC supersaturation can be considerably depleted when the concentration of $\mathrm{CCN}$ is high $\left(>5 \times 10^{3} \mathrm{~cm}^{-3}\right)$. When not accounted for, depletion effects can introduce significant biases in $\mathrm{CCN}$ closure, inferences of particle hygroscopicity, and droplet activation kinetics (Raatikainen et al., 2012, 2013). We correct for such depletion biases following the procedures of Lathem and Nenes (2011) and the updated model of Raatikainen et al. (2012). The experiments of Lathem and Nenes (2011) were performed at ambient pressure while the ARCTAS data was collected at $450 \mathrm{hPa}$; therefore, additional high CCN concentration calibration experiments were conducted at $450 \mathrm{hPa}$ to parameterize the influence of increas- ing $\mathrm{CCN}$ concentration on the calibrated instrument supersaturation at lower pressure. The experimental procedures were identical to Lathem and Nenes (2011), with the addition of a pressure control system to lower and control the CCN pressure at $450 \mathrm{hPa}$. Polydisperse ammonium sulfate particles with total concentration varying between $10^{1}-10^{5} \mathrm{~cm}^{-3}$ were passed through the $\mathrm{CCN}$ instrument to determine the impact on the calibrated supersaturation and droplet size. At each concentration level, the $D_{\mathrm{pc}}$ was calculated from the measured $\mathrm{CCN}$ and dry particle size distribution, and used in Eq. (2) with a prescribed $\kappa$ for ammonium sulfate of 0.6 to determine the effective instrument supersaturation, $s$. The lowest CCN concentration levels $\left(50-100 \mathrm{~cm}^{-3}\right)$ were used to characterize the reference calibrated supersaturation, $s_{0}$, at a given set of operation parameters with no depletion effects. The CCN data and dry particle size distributions were also used in a fully-coupled CCN instrument model (Raatikainen et al., 2012) to simulate the expected changes in supersaturation and droplet size, which were in agreement with the experimental observations. The laboratory experiments and model identified a linear decrease in supersaturation for increasing $\mathrm{CCN}$, which was parameterized for the ARCTAS data set $(450 \mathrm{hPa}$, correlation coefficient of 0.9$)$ as:

$$
\frac{s}{s_{0}}=1-1.61 \times 10^{-5} N_{\mathrm{CCN}}
$$

where $s$ is the instrument supersaturation when the concentration of $\mathrm{CCN}, N_{\mathrm{CCN}}$, is high; and $s_{0}$ is the supersaturation for $N_{\mathrm{CCN}}$ approaching zero. Equation (5) was then used to correct the calibrated supersaturation values (which are equivalent to $s_{0}$ ) for supersaturation depletion. For example, concentrations of $\mathrm{CN}$ and $\mathrm{CCN}$ routinely exceeded $1.5 \times 10^{4} \mathrm{~cm}^{-3}$ during the sampling of fresh biomass burning plumes (Fig. 3), resulting in a $\frac{s}{s_{0}} \leq 0.75$, or a supersaturation depletion of $\geq 25 \%$.

Small changes in the supersaturation can significantly bias the $\mathrm{CCN}$ inferred $\kappa$, due to the dependence of $s_{\mathrm{c}}$ on the term $\left(\kappa D_{\mathrm{p}}^{3}\right)^{-1 / 2}$ in Eq. (2), leading to strongly increasing $\kappa$ as $s$ decreases for the same $D_{\mathrm{p}}$. The relative change in $\kappa$ arising from a given change in supersaturation, $\frac{s}{s_{0}}$, can be represented by:

$\frac{\kappa-\kappa_{0}}{\kappa}=\frac{\Delta \kappa}{\kappa}=1-\left[\frac{s}{s_{0}}\right]^{2}$

where $\kappa_{0}$ is the $\kappa$ inferred assuming $s_{0}$ represents the instrument supersaturation. Following Eq. (6), if $\frac{s}{s_{0}} \approx 0.75$, then $\frac{\Delta \kappa}{\kappa} \approx 0.44$, which indicates the $\kappa_{0}$ at the original uncorrected calibrated $s_{0}$ would be underpredicted by $44 \%$.

\subsection{Air mass source type identification}

The nine research flights for ARCTAS-B were classified into three primary aerosol types, representing the dominant sources of pollution into the Arctic environment. Flight 

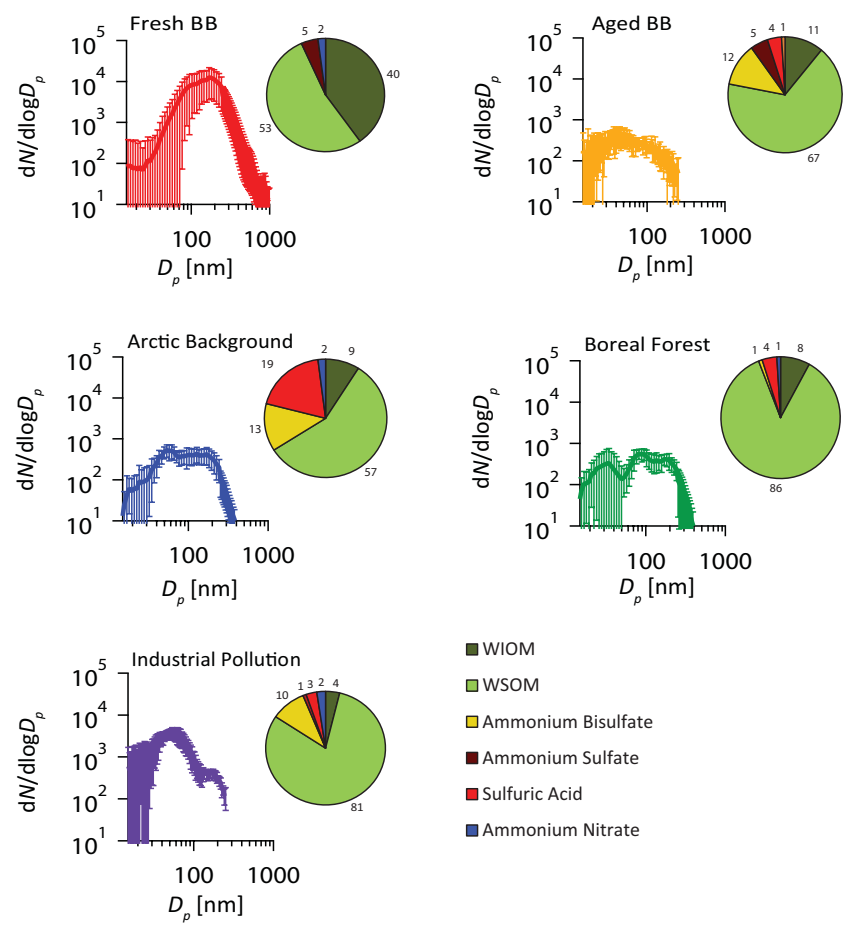

$\square$ WIOM

$\square$ WSOM

$\square$ Ammonium Bisulfate

- Ammonium Sulfate

$\square$ Sulfuric Acid

$\square$ Ammonium Nitrate

Fig. 2. Average dry particle size distributions $\left(\mathrm{d} N / \mathrm{d} \log D_{\mathrm{p}}\right)$ for each air mass source type and average aerosol volume fractions (\%) calculated from the HR-TOF-AMS and PILS-WSOC mass loadings (inset). Water-soluble organic matter (WSOM) is calculated from PIL-WSOC (Sect. 2.3), and water-insoluble organic matter (WIOM) is taken as the difference between WSOM and total organic carbon measured by the HR-TOF-AMS. Error bars on size distributions denote one standard deviation from the mean.

tracks, colored by source type, are shown in Fig. 1. Median size distributions and chemical composition are shown in Fig. 2, while median concentration and activation efficiency are shown in Fig. 3. A numerical summary of the physical and chemical properties of each source type, useful for model inputs, is provided in Table 1. A detailed analysis of all the data follows.

\subsubsection{Fresh and aged biomass burning}

Following Hecobian et al. (2011), Hornbrook et al. (2011), Moore et al. (2011), and Kondo et al. (2011), biomass burning plume air masses were identified by regions where both of the time averaged $\mathrm{CO}$ and $\mathrm{CH}_{3} \mathrm{CN}$ concentrations were greater than $175 \mathrm{ppbv}$ and $0.2 \mathrm{ppbv}$, respectively. Biomass burning was further separated into fresh and aged, based on sampling location and aerosol loadings. All fresh biomass burning emissions were sampled in the region of active fires in Canada within the boundary layer, while aged biomass burning aerosol was sampled over the high Arctic, indicating long-range transport from Siberia (Fuelberg et al., 2010). Cubison et al. (2011) characterizes the increase in $\mathrm{O}: \mathrm{C}$ with aging for the fire plumes, and confirms that the fresh plumes aged substantially in several hours of daytime transport, and that the long-range transported plumes were substantially more aged than the plumes originating in Canada. As reported by Singh et al. (2010), the observed physical and chemical properties of the fire plumes were similar, despite variations in burn locations, fuel types, and meteorological conditions, as is discussed further in Sect. 4.2.

\subsubsection{Boreal forest and Arctic background}

Air masses of the clean background boreal forest and Arctic were characterized by both time averaged $\mathrm{CO}$ and $\mathrm{CH}_{3} \mathrm{CN}$ concentrations being less than $170 \mathrm{ppbv}$ and $0.1 \mathrm{ppbv}$, respectively (Moore et al., 2011). The background data was further separated into boreal forest and Arctic backgrounds according to latitude of the sample and underlying vegetation. Flights over forested regions South of $66^{\circ} \mathrm{N}$ were classified as boreal forest and flights over ice, sea-ice or open ocean North of $66^{\circ} \mathrm{N}$ were classified as Arctic background.

\subsubsection{Anthropogenic/industrial aerosol}

Limited measurements of anthropogenic aerosol were intercepted during ARCTAS-B, with the most notable sample occurring during Flight 23 in the vicinity of the Canadian oil sands operations at Fort McMurray $\left(56.7^{\circ} \mathrm{N}, 111.4^{\circ} \mathrm{W}\right)$. An up to threefold increase in $\mathrm{CN}$ particle concentration (against background levels) was observed (Fig. 3). Significant increases in $\mathrm{SO}_{2}, \mathrm{CO}$, and $\mathrm{NO}_{\mathrm{x}}$ were also observed above background levels (Simpson et al., 2010).

\section{Results and discussion}

\subsection{Aerosol physical and chemical properties by source type}

The physical and chemical properties of each Arctic source type are summarized below, as well as in Table 1 and Fig. 2. Median CN number densities are reported from a CPC3010 , median CCN number densities are reported at $0.55 \%$ $( \pm 0.05 \%)$ supersaturation from the CCNC, size distributions are reported from the SMPS and UHSAS merged distributions, and volume averaged chemical composition are provided by the HR-ToF-AMS and PILS-WSOC. A supersaturation of $0.55 \%$ was chosen to present $\mathrm{CCN}$ data due to greater data availability across all source types and to provide an upper limit for the $\mathrm{CCN}$ concentration and activation ratios expected in these regions.

Figure 4 shows plots of $\mathrm{CN}$ and $\mathrm{CCN}$ concentrations as a function of latitude for all flights, colored by the aerosol source type. It is clear that the highest concentrations occur within $50-60^{\circ} \mathrm{N}$ latitude and that biomass burning and industrial emissions can significantly enhance the concentrations in this region by $1-2$ orders of magnitude compared to background levels. It is also important to note the wide range 

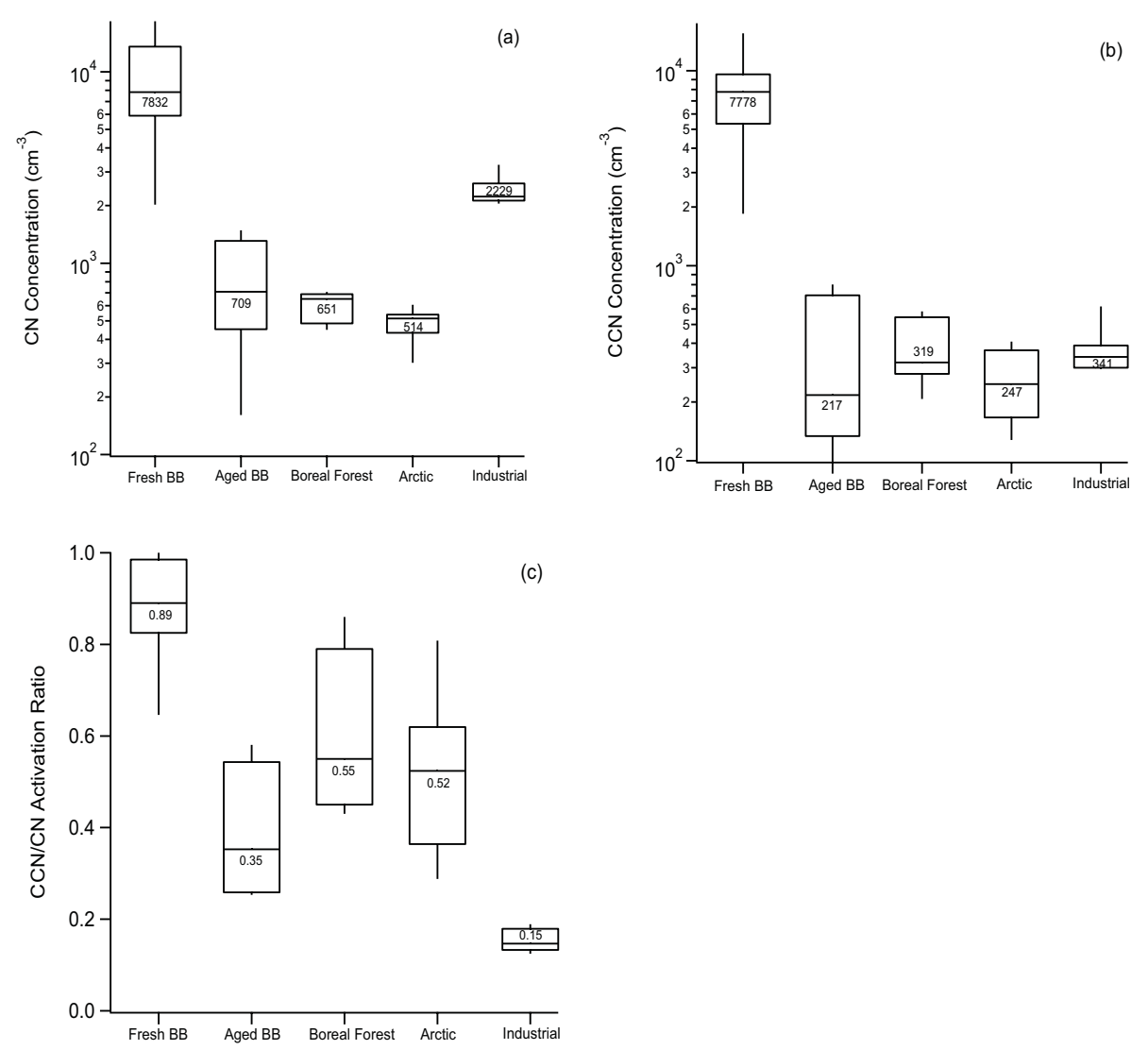

Fig. 3. Aerosol $(\mathrm{CN})$ particle concentration (diameter $>10 \mathrm{~nm})(\mathbf{a}), \mathrm{CCN}$ particle concentration at $0.55 \%$ supersaturation $(\mathbf{b})$ and $\mathrm{CCN} / \mathrm{CN}$ activation ratios at $0.55 \%$ supersaturation (c). Horizontal bars and corresponding values in the boxes represent median concentrations, the box defines the first and third quartiles, and the bars represent the 10th and 90th percentiles. Biomass burning is abbreviated BB.

of variability in $\mathrm{CN}$ and $\mathrm{CCN}$ above $70^{\circ} \mathrm{N}$, where concentrations varied from as few as $10 \mathrm{~cm}^{-3}$ to greater than $10^{3} \mathrm{~cm}^{-3}$, which is a level of variability that could have significant impacts on the direct and indirect radiative forcing in the Arctic environment, where concentrations are generally less than $100 \mathrm{~cm}^{-3}$ (Moore et al., 2012).

\subsubsection{Fresh and aged biomass burning}

As shown in Fig. 3, fresh biomass burning aerosol from our sample data in Canada had median CN number densities of $7832 \mathrm{~cm}^{-3}$. Median CCN concentrations and activation ratio (at $0.55 \%$ supersaturation) were $7778 \mathrm{~cm}^{-3}$ and 0.89 , respectively. Aged biomass burning emissions were sampled over the high Arctic $\left(83^{\circ} \mathrm{N}\right.$, indicating long range transport from Siberia) and had median $\mathrm{CN}$ and CCN number densities of $709 \mathrm{~cm}^{-3}$ and $217 \mathrm{~cm}^{-3}$, respectively, resulting in a median activated fraction of 0.35 . The lower activated fraction of the aged biomass burning is mostly attributable to a smaller size mode, likely as a result of wet depositional losses and heterogeneous chemical processing with transport (Brock et al., 2004; Dunlea et al., 2009). The median size for fresh biomass burning aerosol was $146 \pm 2 \mathrm{~nm}$, whereas it was only $48 \pm 1 \mathrm{~nm}$ for the aged biomass burning aerosol (Fig. 2, Table 1). The median size of the aged biomass burning aerosol sampled over the high Arctic is much smaller than that observed by Moore et al. (2011) over Alaska, where a mean diameter of $189 \mathrm{~nm}$ was observed.

Organics dominated the non-refractory aerosol volume in both fresh and aged biomass burning, representing, on average, $93 \%$ and $78 \%$, respectively (Fig. 2). Of the organic component, a significant fraction of the OC was WSOM (57\% for fresh biomass burning and $80 \%$ for aged biomass burning), which is in agreement with existing observations of biomass burning OC and WSOM (Fu et al., 2009; Kondo et al., 2011). WSOM significantly increased for aged biomass burning, which is consistent with expectations of organic species becoming more polar and soluble with oxidative aging in the atmosphere (Ng et al., 2011; Duplissy et al., 2011) and the observed increase of $\mathrm{O}: \mathrm{C}$ and decrease of primary species with aging for these biomass burning plumes (Cubison et al., 2011). Kondo et al. (2011) also found that a large majority of the sampled biomass burning particles did not contain significant amounts of black carbon (average volume fraction 2-4\%), suggesting the biomass burning particles were well aged. Ammonium sulfate, ammonium bisulfate, 

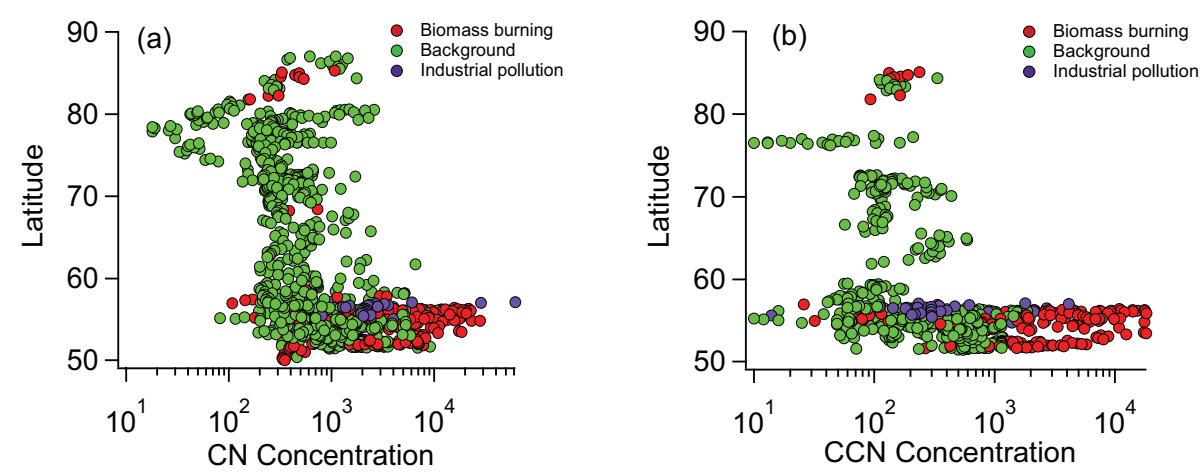

Fig. 4. $\mathrm{CN}$ (a) and $\mathrm{CCN}$ (b) number concentration $\left(\mathrm{cm}^{-3} \mathrm{STP}\right)$ as a function of latitude, colored by source type, for all ARCTAS-B research flights.

ammonium nitrate, and sulfuric acid represent less than $10 \%$ of total volume; however, these species tended to increase in the aged biomass burning up to $22 \%$ total volume (Fig. 2). Similar compositions for aged biomass burning were observed in the Alaskan Arctic by Moore et al. (2011), and for fresh biomass burning over Wyoming (Pratt et al., 2011), with organics representing $70-80 \%$ of aerosol volume and mass.

\subsubsection{Boreal forest and Arctic background}

The median number density of $\mathrm{CN}$ and $\mathrm{CCN}$ in both the boreal forest and Arctic background environments were generally low and less variable. For the boreal forest, median $\mathrm{CN}$ number densities were $651 \mathrm{~cm}^{-3}$ and $\mathrm{CCN}$ number densities were $319 \mathrm{~cm}^{-3}$, resulting in a median activated fraction of 0.55. For the Arctic background, median CN number densities were $514 \mathrm{~cm}^{-3}$ and $\mathrm{CCN}$ number densities were $247 \mathrm{~cm}^{-3}$, resulting in a median activated fraction of 0.52 . The particle size distributions for both background environments were bimodal, with peaks in both the accumulation and Aitken modes (Fig. 2, Table 1), as also observed by Moore et al. (2011) and Brock et al. (2011) for the Alaskan Arctic during 2008. Since these areas are devoid of primary combustion particles and the lifetime of Aitken mode particles is short, these observations suggest the importance of new particle formation in these environments (Chang et al., 2011).

For the boreal forest, organics constituted $94 \%$ of the aerosol volume, with $91 \%$ of the OC being WSOM. Sulfuric acid, ammonium bisulfate and ammonium nitrate represented $5 \%, 2 \%$ and $1 \%$ of the total aerosol volume, respectively. For the Arctic background, organics were less dominant, constituting only $66 \%$ of the total volume, with $87 \%$ of the OC being WSOM. The remaining volume was divided between $18 \%$ sulfuric acid, $13 \%$ ammonium bisulfate, and $2 \%$ ammonium nitrate. The Arctic aerosol organic component measured in this study was higher than the $36 \%$ reported by Martin et al. (2011) over the summertime high
Arctic pack ice and $51 \%$ measured by Moore et al. (2011) in the springtime Alaskan Arctic, but had overall high variability $(66 \pm 22 \%$, Table 1$)$. The larger organic fraction during the summer as compared to the spring is likely due to the increased importance of biogenic SOA and biomass burning sources in the summer.

\subsubsection{Anthropogenic/industrial aerosol}

The median $\mathrm{CN}$ number density for the industrial aerosol plume in the vicinity of Fort McMurray was $2229 \mathrm{~cm}^{-3}$ and the median $\mathrm{CCN}$ number density was $341 \mathrm{~cm}^{-3}$, resulting in a median activated fraction of only 0.15 . This low activated fraction suggests the particles are either too small or insufficiently hygroscopic to activate. The particle size distribution suggests the former is the likely reason, as the distribution was bimodal, with the dominant mode at $52 \mathrm{~nm}$. Another mode was present at $154 \mathrm{~nm}$, indicating external mixing of the industrial pollution with the boreal forest background. The anthropogenic particles are too small to be efficient CCN near the source, but these industrial emissions could potentially be a large source of $\mathrm{CCN}$ further downwind as the particles age and their mean size increases as the $\mathrm{SO}_{2}$ from the plumes is converted to sulfate.

AMS data indicated $84 \%$ of the aerosol volume of the particles in the industrial plumes was organic, with $95 \%$ of this OC being WSOM. However, this chemical composition is more likely representative of the larger, boreal forest background mode, since the mass of the accumulation mode is estimated to be 10 times larger than that of the small mode, and possibly also since the AMS has limited detection efficiency for particles less than $50 \mathrm{~nm}$ (Jimenez et al., 2003). In fact, the measured chemical composition is in excellent agreement with measurements from the boreal forest background (Fig. 2, Table 1). This confirms that the smaller, industrial mode represented a very small fraction of the submicron mass, and that the larger boreal forest background aerosol dominated the bulk composition. When using the measured size distributions and chemical composition to predict $\mathrm{CCN}$, 
significant overprediction biases occurred on the order of $150 \%$ (Sect. 4.3, Table 2). This confirms the industrial emissions are externally mixed with the aerosol background and altering the bulk composition of the total aerosol population beyond its natural state.

\subsection{Particle hygroscopicity, $\kappa$}

In Fig. 5, inferred $\kappa$ from measurements of CCN activity and particle size distributions are compared with $\kappa$ calculated directly from HR-ToF-AMS and PILS-WSOC composition, using Eqs. (2) and (3) and assuming $\kappa_{\text {org }}=0.12 \varepsilon_{\text {WSOM }}$. Despite differences in the physical and chemical properties of the aerosol from the different environments, the inferred $\kappa$ from CCN measurements was fairly uniform with $\kappa=0.08$ 0.32 , consistent with organics dominating particle water uptake and also consistent with the $\kappa=0.1-0.3$ reported for various air mass types sampled by Moore et al. (2011) in the spring Alaskan Arctic. However, the variability in the inferred and calculated $\kappa$ for the Arctic background was large, with $\kappa=0.32 \pm 0.21$. This variability is mostly attributed to large variations in the volume fractions of the inorganic species, which varied from $6 \%$ to $70 \%$. Because the inorganic species have much higher $\kappa(\kappa=0.61-0.9)$ compared to the organics $(\kappa=0.12)$ (Petters and Kreidenweis, 2007), large variations in inorganic volume fraction is expected to have large impacts on aerosol $\kappa$. Some of the variability could also arise from the assumptions of size-independent composition and internally mixed aerosol. High variability in Arctic aerosol $\kappa$ has also been observed in several previous studies, such as Martin et al. (2011) who inferred a total $\kappa$ for the high Arctic of $0.33 \pm 0.13$ and Kammermann et al. (2010) who measured at the remote subarctic Stordalen mire in Sweden and found $\kappa$ to vary between 0.07-0.21.

Surprisingly, the inferred $\kappa$ was invariant between aged biomass burning plumes transported from Siberia and fresh biomass burning smoke sampled directly over active fires in Canada, with both having CCN inferred $\kappa \approx 0.18 \pm 0.13$. A $\kappa$ of $\sim 0.2$ for biomass burning suggests that water uptake for the particles is determined by soluble organics, which dominate the aerosol volume (Sect. 4.1). Recent laboratory studies suggest that very fresh biomass burning particles are less hygroscopic (have a lower $\kappa$ ) than aged biomass burning, but the $\kappa$ can be highly variable $(\kappa=0.02-0.8)$ based on the fuel type, inorganic to organic fraction, and burning conditions (Petters et al., 2009; Carrico et al., 2010; Engelhart et al., 2012). Engelhart et al. (2012) also found evidence for rapid evolution of the $\kappa$ of primary biomass burning aerosol by performing smog chamber studies of smoke from fuels representative of North American wildfires. They found the $\kappa$ for the primary biomass burning aerosol to be highly variable between 0.06 and 0.6 depending on fuel type, but all samples generally converged to a value of $0.2 \pm 0.1$ after just a few hours of photochemical aging, which is in excellent agreement with our ambient observations. This laboratory and am-

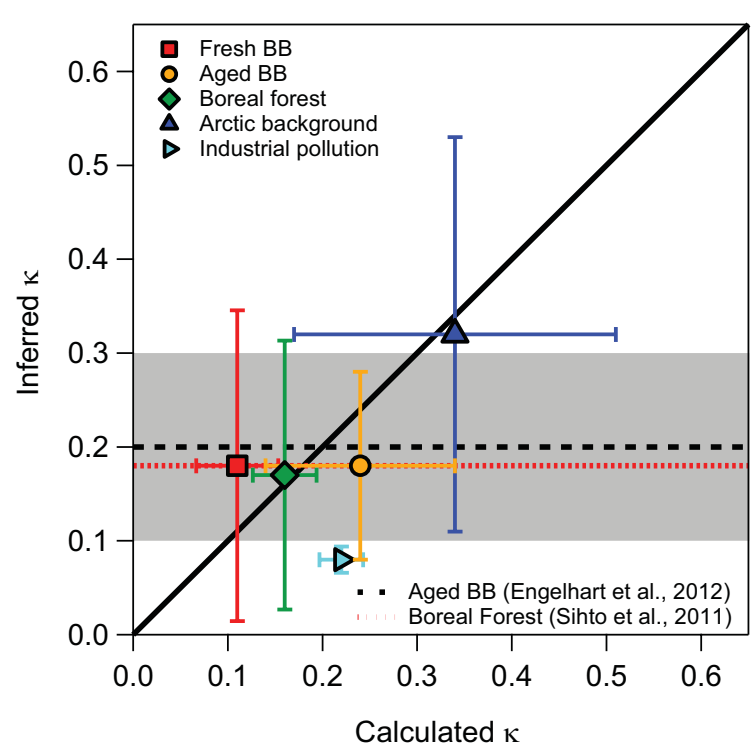

Fig. 5. $\kappa$ inferred from CCN measurements vs. $\kappa$ calculated from HR-ToF-AMS and PILS-WSOC chemical composition for each source type assuming that composition is size-independent and internally mixed. Error bars denote one standard deviation from the mean. Dashed lines indicate reported literature $\kappa$ values for aged biomass burning (BB) (Engelhart et al., 2012) and boreal forest aerosol (Sihto et al., 2011). Shaded area indicates the standard deviation in the reported literature values of $\kappa$.

bient data, together with in-situ chemical evolution data $(\mathrm{Cu}-$ bison et al., 2011), strongly suggests that atmospheric processing can quickly alter the diverse aerosol properties, such that they converge to a similar $\kappa$ and $\mathrm{CCN}$ activity in the atmosphere. Such rapid aging and evolution of aerosol could be significant for modeling studies, as this dramatically reduces the complexity and variability of $\kappa$ and aging processes required for model representation.

The inferred $\kappa$ do not always agree with the $\kappa$ calculated based on HR-ToF-AMS and PILS-WSOC bulk chemical composition, assuming the $\kappa_{\text {org }}=0.12 \varepsilon_{\text {WSOM }}$. The inferred $\kappa$ for the fresh biomass burning and boreal forest background aerosol are slightly higher than the calculated values, but generally within the level of variability, and also in agreement with other published studies (Sihto et al., 2011; Engelhart et al., 2012). Size-varying chemical composition or non-CCN active particles could also result in discrepancies between the inferred and calculated $\kappa$, since both approaches used in Fig. 5 assume an internally mixed, bulk composition (e.g., Cerully et al., 2011). This type of bias was only observed for the industrial pollution case, where the aerosol was significantly externally mixed and large discrepancies between the different $\kappa$ was observed (Fig. 5).

The inferred $\kappa$ for the industrial pollution $(\kappa=0.08)$ is much lower than calculated $(\kappa=0.22)$, with much less overall variability. The primary reason for this difference is that the bulk composition measurements from the HR-ToF-AMS 
and PILS-WOSC are dominated by the larger particle sizes, where most of the aerosol mass resides (refer to Sect. 4.1.3). Size dependent composition or non-CCN active modes could also reduce the $\mathrm{CCN}$ inferred $\kappa$, which would not be represented by the bulk composition derived $\kappa$. For example, for the industrial pollution, the chemical composition suggests a predominately soluble organic composition $(81 \%$ by volume, Fig. 2) and thus a high calculated $\kappa$, whereas the $\mathrm{CCN}$ activity indicates a much lower $\kappa$, likely attributable to the industrial mode at $\sim 52 \mathrm{~nm}$ being weakly to non-hygroscopic. As discussed further in Sect. 4.3, the industrial mode $\kappa$ needs to be $\sim 0.06$ for CCN closure to be obtained. Size resolved HR-ToF-AMS composition in such environments is desired, but was unavailable during this flight period, due to the use of a fast "plume capture" mode that does not include sizeresolved measurements.

\subsection{CCN closure}

Predictions of $\mathrm{CCN}$ concentrations in climate models require simplifying assumptions, particularly in the description of chemical composition and aerosol mixing state, and the resulting uncertainty in indirect forcing from their application needs to be quantified (e.g., Sotiropoulou et al., 2007; Moore et al., 2012). To address this need for the Arctic environment, $\mathrm{CCN}$ closure studies were performed for each of the regional aerosol types using Köhler theory, testing assumptions regarding aerosol mixing state and hygroscopicity of the organics. In this study, we test the applicability of bulk (size-independent) composition for internally or externally mixed aerosol populations, which represent some of the simplest, yet robust and efficient, descriptions of aerosol CCN activity for global models. Additionally, the organic component of the aerosol was treated as either completely insoluble $\left(\kappa_{\text {org }}=0\right)$ or the measured WSOC volume fraction, $\varepsilon_{\mathrm{WSOC}}$, was converted to $\varepsilon$ WSOM (refer to Sect. 2.3 for OC to OM conversion discussion) and used to parameterize the organic hygroscopicity as $\kappa_{\text {org }}=0.12 \varepsilon_{\text {WSOM }}$. This approach assumes that only the WSOM fraction of the organic is hygroscopic, and the $\kappa$ of the WSOM is assigned a value of 0.12 , consistent with assuming an organic density of $1400 \mathrm{~kg} \mathrm{~m}^{-3}$, an organic molar mass of $0.2 \mathrm{~kg} \mathrm{~mol}^{-1}$, and a van't Hoff factor of unity (Engelhart et al., 2008; Asa-Awuku et al., 2010; Engelhart et al., 2011; Moore et al., 2011). A similar approach was used by Bougiatioti et al. (2009), where excellent CCN closure was achieved in the East Mediterranean by using measured WSOC and using $\kappa_{\text {org }}=0.16 \varepsilon_{\text {WSOC }}$.

Three different closure scenarios were tested, including: (1) internally mixed aerosol with insoluble organics, (2) internally mixed aerosol with soluble organics, and, (3) externally mixed aerosol, where each particle contains either only organic species (of which a fraction is soluble) or only inorganic species. For each assumption of aerosol mixing state and chemical composition, the particle $\kappa$ was calculated and used with Eq. (2) to determine the critical dry particle acti- vation diameter, $D_{\mathrm{pc}}$, at a given supersaturation. The number of CCN was then derived from the $D_{\mathrm{pc}}$ by integrating the measured size distribution from $D_{\mathrm{pc}}$ to the largest measured size, using Eq. (4). The predicted CCN for each closure scenario was then compared to measurements from the CCNC. The relative error between the measured and predicted CCN concentrations was used to assess the performance of each closure scenario and determine which simplifications best matched observations.

A summary of the closure errors for each closure scenario and source type is shown in Table 2. Treating the organics as insoluble resulted in significant underpredictions in $\mathrm{CCN}$ number, especially for the fresh biomass burning $(-44 \pm 16 \%)$ and boreal forest background $(-45 \pm 8 \%)$ environments. This highlights the importance of the WSOM fraction for improving predictions of the $\mathrm{CCN}$ activity of Arctic aerosol, as has also been shown by Asa-Awuku et al. (2011) for urban pollution in Texas and by Bougiatioti et al. $(2009,2011)$ for well-aged aerosol sampled in Crete, Greece. Including the measured WSOM (with hygroscopicity represented as $\kappa_{\text {org }}=0.12 \varepsilon_{\text {WSOM }}$ ) improved closure for an internally mixed aerosol assumption, but in some cases also led to a general overprediction of CCN (8-30\%, on average). These overprediction errors decreased to less than $25 \%$ for all environments, except industrial pollution, when the aerosol was assumed to be externally mixed (Fig. 6). These findings are consistent with Moore et al. (2012), who compare reported closure errors from 36 different published CCN studies around the world and find closure errors to generally improve for an assumption of externally mixed aerosol with soluble organics, even though data was not always present to determine the aerosol mixing state. It is also important to note the extremely high observed $\mathrm{CCN}$ concentrations (up to $10^{4} \mathrm{~cm}^{-3}$ ) for fresh biomass burning (Fig. 6). At these high concentration levels, supersaturation depletion becomes significant ( $>25 \%$ ), and must be accounted to ensure unbiased $\mathrm{CCN}$ measurements. Neglecting the supersaturation depletion in the biomass burning environments biases the reported CCN prediction errors by an additional 10-20\%, highlighting the importance to accurately quantify and account for this measurement artifact in high concentration environments.

CCN closure for the Arctic background was within $-1 \pm 15 \%$ for the external aerosol case (Table 2), which is in agreement with the findings of Moore et al. (2011) for the Alaskan Arctic in spring; however, an externally mixed aerosol may not always be representative of the Arctic background in summer. Martin et al. (2011) found an internally mixed assumption to provide the best $\mathrm{CCN}$ closure for the Arctic in summer, while Kammermann et al. (2010) achieved closure to within $11 \%$ regardless of the assumed mixing state. The closure error for fresh biomass burning and boreal forest also varied with supersaturation, tending towards larger underpredictions (up to $24 \%$ ) at higher supersaturation. This is suggestive of a size-dependent chemical composition, where the smaller particles (which activate at 


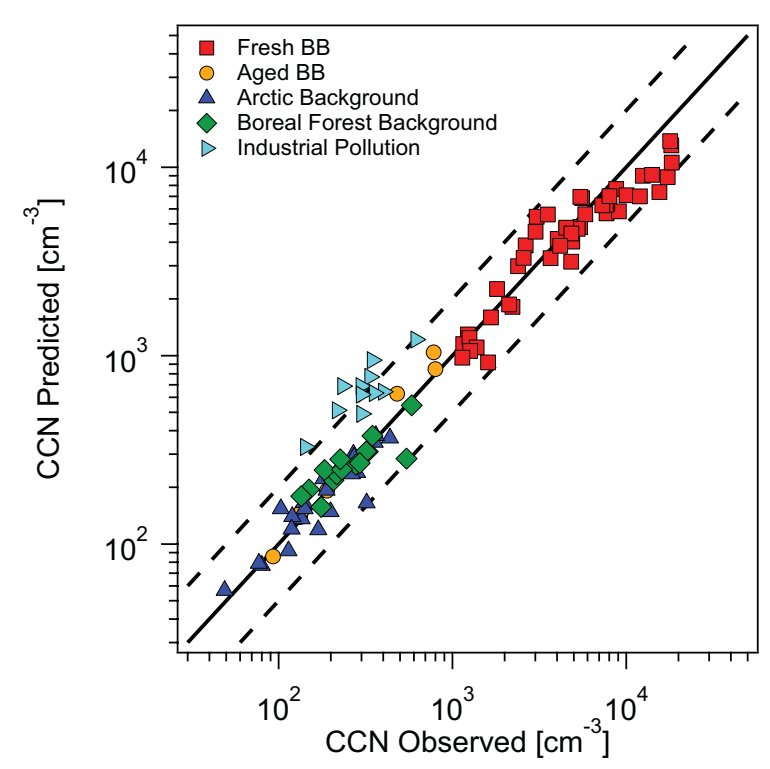

Fig. 6. CCN closure plot for each source type assuming externally mixed aerosol with soluble organics. Solid line represents the $1: 1$ agreement, while the dashed lines represent $\pm 50 \%$ error bars.

higher supersaturation) may have a higher soluble fraction and/or higher $\kappa$ (e.g., Agarwal et al., 2010; Bougiatioti et al., 2011). The observed CCN underpredictions at high supersaturation could be reduced if the $\kappa$ for the biomass burning WSOM at smaller sizes is higher than the prescribed bulk value of 0.12 . Previous studies of water-soluble extracts from biomass burning and secondary organic aerosol support a higher $\kappa$ for the water-soluble fraction, such that $\kappa_{\text {org }}=(0.25 \pm 0.05) \varepsilon_{\text {WSOM }}$ (Asa-Awuku et al., 2008; Padró et al., 2010; Engelhart et al., 2011; Asa-Awuku et al., 2011). While a higher $\kappa$ of 0.25 for the WSOM might help explain the $\mathrm{CCN}$ underpredictions for biomass burning at high supersaturation (Table 2), using a bulk $\kappa$ of 0.25 for the rest of the data set would lead to more significant overpredictions. Furthermore, Moore et al. (2011) found excellent CCN closure for a $\kappa_{\text {org }}=0.11$ in the Alaskan Arctic, which suggests the organic hygroscopicity in the Arctic might be lower. From these examples, it is important to note that a bulk, sizeaveraged $\kappa$ for the organic or WSOM is not always suitable for every environment.

It is also important to note that even an external mixture assumption (which often gives excellent CCN closure even if it does not fully represent the aerosol) is not sufficient to correctly predict the $\mathrm{CCN}$ concentrations for the industrial pollution case, with overprediction errors of $105-153 \%$. In this case, the bulk composition measurements are most likely inconsistent with the actual size varying aerosol composition, due to the small mass fraction represented by the Aitken mode. Assuming the HR-ToF-AMS bulk composition applies to both modes of the measured size distribution $(52 \mathrm{~nm}$ and $154 \mathrm{~nm}$, respectively) is incorrect, since this assumption implies that a large fraction of the hydrocarbon-like aerosols and $\mathrm{BC}$ in the fresh industrial plumes are hygroscopic and can serve as $\mathrm{CCN}$, which leads to the large overprediction errors. Actually, the $\kappa$ of the smaller industrial mode at $52 \mathrm{~nm}$ is much less and would have to be close to 0.06 in order to accurately predict $\mathrm{CCN}$ concentrations in this environment. These results are in agreement with Wang et al. (2010) who find that mixing state strongly influences the calculated CCN only when weak or non-hygroscopic species (such as primary organic aerosol or black carbon) contribute a substantial fraction of the aerosol volume, as is the case for these industrial emissions.

These results indicate, that for the majority of air masses representative of the Arctic, $\mathrm{CCN}$ can be accurately predicted by assuming bulk aerosol chemical composition and using an external mixture of pure inorganic and organic species, with the organic hygroscopicity defined by the WSOM. The only exceptions are in the vicinity of strong point sources of industrial pollution, where a separate $\kappa$ for each mode of the size distribution is required, and for fresh biomass burning aerosol, where smaller sizes may have higher WSOM $\kappa$.

\subsection{Aging and evolution of biomass burning aerosol}

Condensation of secondary species (e.g., sulfate, nitrate, organics) onto particles is an important, and potentially dominant, pathway for the transformation from primary biomass burning particles into more hygroscopic ones. Although SOA formation in these biomass burning plumes did not lead to a net increase in organic mass (Cubison et al., 2011; Hecobian et al., 2011), aerosol aging was observed in a few hours after emission, which likely involved gas-phase oxidation of semivolatile species (Cubison et al., 2011), and possibly also redistribution of primary semivolatile species across different particles (Marcolli et al., 2004). Organic species are expected to become more polar and soluble with oxidative aging in the atmosphere (Ng et al., 2011; Duplissy et al., 2011), such that a correlation between $\kappa_{\text {org }}$ and $\mathrm{O}: \mathrm{C}$ exists (Jimenez et al., 2009; Lambe et al., 2011).

Figure 7 shows the relationship between the inferred $\kappa_{\text {org }}$ from CCN measurements and the HR-ToF-AMS derived $\mathrm{O}: \mathrm{C}$ ratio for the direct sampling of fresh biomass burning aerosol for ARCTAS Flight 18 in the vicinity of Lake MacKay in Saskatchewan, Canada. $\kappa_{\text {org }}$ does not strongly increase with $\mathrm{O}: \mathrm{C}$ as expected; however, the variability in observed $\mathrm{O}: \mathrm{C}$ is not sufficiently large to observe significant changes in $\kappa_{\text {org }}$. While it is possible that the aerosol composition may be changing in a way that $\mathrm{O}: \mathrm{C}$ alone does not capture, the available aerosol composition measurements are not able to discern this. The range of $\mathrm{O}: \mathrm{C}$ observed, 0.5 for fresh biomass burning emissions and 0.7 for more aged ones (Cubison et al., 2011), confirms the aerosol is composed of oxidized organics (Aiken et al., 2008); however, the inferred values of $\kappa_{\text {org }}(0.1 \pm 0.05)$ are mostly lower than predicted by the Chang et al. (2010) parameterization and 


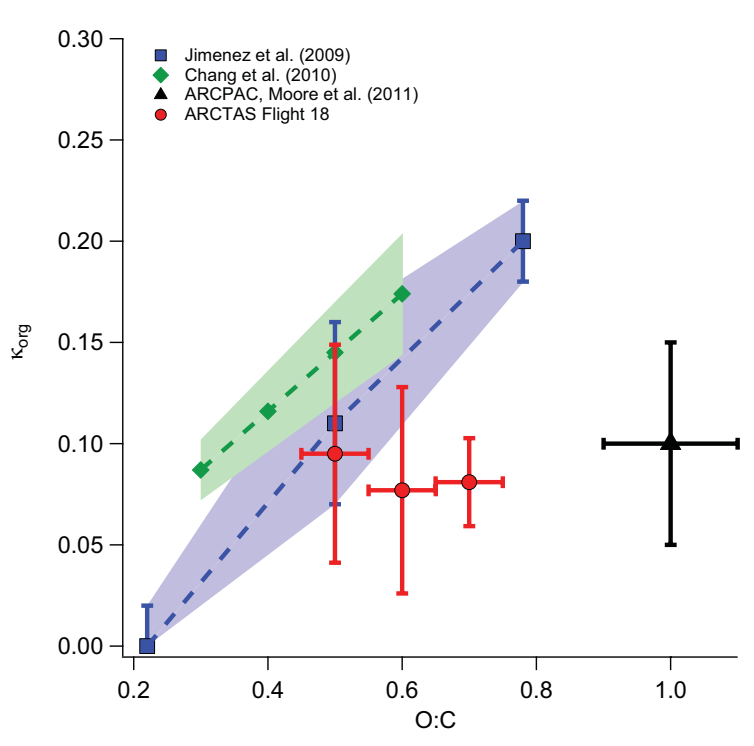

Fig. 7. Inferred $\kappa_{\text {org }}$ vs. HR-ToF-AMS derived O : C ratios. Markers denote observed relationships published by Chang et al. (2010) in rural Egbert, Ontario, Canada (green) and Jimenez et al. (2009) for a variety of ambient and laboratory organic aerosols (blue). Shaded area represents the reported standard deviation from the mean. Black triangle represents the average values observed during the 2008 ARCPAC campaign for biomass burning influenced air masses (Moore et al., 2011). Red circles indicate average values observed for biomass burning plumes sampled during ARCTAS Flight 18.

observations reported by Jimenez et al. (2009) (shaded areas of Fig. 7). Evidence for fast physical aging of the ARCTAS biomass burning black carbon aerosol was also observed by Kondo et al. (2011), who observed black carbon particles to be thickly coated with secondary organic species $1-2 \mathrm{~h}$ after emission. Any further aging or increase in aerosol oxidation for these fresh biomass burning plumes was not observed during the timescale of these aircraft measurements; however, additional aging was observed for the transported Asian plumes (Cubison et al., 2011). Similarly low $\kappa$ values at high $\mathrm{O}: \mathrm{C}$ ratios and organic volume fraction $(>80 \%)$ were also observed by Moore et al. (2011) in the Alaskan Arctic, with total aerosol $\kappa$ approaching a limit of $0.15 \pm 0.05$ for an $\mathrm{O}: \mathrm{C}$ of 1.0 (Fig. 7).

\section{Conclusions}

Measurements of aerosol properties, chemical composition, and $\mathrm{CCN}$ for nine research flights during the ARCTAS-B campaign sampled some of the primary sources of aerosol in the summertime Arctic, including samples from fresh and aged biomass burning, boreal forest background, Arctic background, and industrial emissions. The observations show significant variability in total $\mathrm{CN}$ and $\mathrm{CCN}$ concentrations, with biomass burning and industrial emissions in- creasing particle concentrations by 1-2 orders of magnitude against the pristine Arctic background. A significant fraction of the aerosol in all environments (66-94\% by volume) is made of organic species, with the highest organic loads present in the boreal forest background and biomass burning samples. Of this organic carbon, greater than $57 \%$ is watersoluble, contributing significantly to particle hygroscopicity and CCN activity. The Arctic background had the highest and most variable inferred hygroscopicity parameter, $\kappa$, of $0.32 \pm 0.21$, consistent with a lower (and more variable) observed organic aerosol fraction. This high variability suggests that the Arctic $\kappa$ may exhibit large regional and seasonal variability arising from variations in transport and organic loadings, and this variability could be significant for understanding and parameterizing the CCN activity of Arctic aerosol. Future Arctic field studies should seek to further quantify the regional and seasonal variability in $\kappa$.

The inferred $\kappa$ for aged and fresh biomass burning were both consistent and representative of aged organics with a $\kappa=0.18 \pm 0.13$, in accord with observations that emissions of primary aerosol directly over active fires rapidly age in the atmosphere on the timescale of a few hours (Cubison et al., 2011), converging the diverse primary aerosol properties to the $\kappa$ and CCN activity close to those of aged organics. A correlation between $\kappa_{\text {org }}$ and $\mathrm{O}: \mathrm{C}$ was not observed for the fresh biomass burning aerosol, suggesting that additional aging does not increase the hygroscopicity of the organic species, and a limit of $\kappa_{\text {org }}$ of $0.1 \pm 0.05$ resulting from oxygenation is approached within a few hours after emission. Such rapid aging has also been observed in chamber studies of fresh biomass burning aerosol (Engelhart et al., 2012) and in other in-situ measurements in the Arctic (Moore et al., 2011; Cubison et al., 2011), which suggests that this could be a potentially significant finding for reducing the complexity required for global atmospheric models to simulate atmospheric aging of biomass burning. Rather than needing to know the hygroscopic properties of aerosol from individual fires, an understanding of the overall aged particles after a few hours may be all that is required, as it is the aged smoke that forms the regional and mixed hazes that most influence climate.

CCN closure was assessed using Köhler theory along with compositional simplifications in aerosol mixing state and organic hygroscopicity $\left(\kappa_{\text {org }}\right)$ employed by global models. The best $\mathrm{CCN}$ predictions $(<25 \%$ relative error, on average, for all environments) were achieved by assuming a sizeaverage chemical composition, an external mixture of inorganics and organics, and with the hygroscopicity of the organics parameterized by the $\kappa$ of the WSOM fraction, where $\kappa_{\mathrm{org}}=0.12 \varepsilon_{\text {WSOM}}$. Neglecting the hygroscopicity of the water-soluble organics resulted in systematic underpredictions of CCN activity on the order of $30-50 \%$. Therefore, the assumption that the WSOM component drives hygroscopicity for the entire organic fraction is sufficient for the Arctic environment, with only measurements of the OC 
and WSOC present in atmospheric particles needed for accurate $\mathrm{CCN}$ predictions. The only exception is in the vicinity of the Canadian oil sands industrial pollution, where a sizedependent chemical composition and external mixture (represented as a separate $\kappa$ for each mode of the distribution) was needed for CCN closure. It is important to characterize and understand the impacts of these industrial emissions, as they are expected to increase significantly in the future with increased Arctic oil exploration and shipping (McLinden et al., 2012).

These measurements are for a fairly large geographical area $\left(50-85^{\circ} \mathrm{N}, 40-130^{\circ} \mathrm{W}\right)$ of the Arctic, but for limited temporal sampling in the summertime (26 June-14 July 2008). Aerosol sources in the Arctic are known to have a seasonal cycle, where changes in long-range transport, solar irradiance, and ambient temperature can significantly influence the chemical composition and hygroscopicity of the aerosol. However, these results are consistent with measurements conducted during the Alaskan Arctic during the spring (Moore et al., 2011), which suggest the overall hygroscopicity ranges between $\kappa=0.1-0.32$. The variability in Arctic $\kappa$ and CCN is likely to be driven by variations in the watersoluble organic content. Including real-time measurements of the WSOM fraction can significantly improve CCN predictions, and a simple parameterization of the $\kappa_{\text {org }}$ is all that is required, which can greatly simplify model inputs and potentially reduce the uncertainty of aerosol water uptake and cloud radiative forcing in global climate models. A novel correction of the $\mathrm{CCN}$ instrument supersaturation for water vapor depletion resulting from high concentrations of $\mathrm{CCN}$ was also applied. Care should be taken to account for supersaturation depletion in high concentration environments, such as biomass burning plumes, because a supersaturation depletion of just $30 \%$ (arising from $\mathrm{CCN}$ concentrations of $10^{4} \mathrm{~cm}^{-3}$ ) can bias CCN closure prediction errors by an additional $20 \%$ and result in underestimating $\kappa$ by as much as $50 \%$.

Acknowledgements. AN and TLL acknowledge support from NASA NNX08AQ99G and an NSF CAREER award. TLL acknowledges support from a NASA GSRP Fellowship, NSF Fellowship, and Georgia Tech Institutional Fellowship. RJW and AH acknowledge support from NASA NNX08AH80G. MJC and JLJ acknowledge support from NASA NNX08AD39G and NNX12AC03G and DOE (BER, ASR program) DE-FG0211 ER65293.

Edited by: P. Quinn

\section{References}

Aiken, A. C., DeCarlo, P. F., Kroll, J. H., Worsnop, D. R., Huffman, J. A., Docherty, K. S., Ulbrich, I. M., Mohr, C., Kimmel, J. R., Sueper, D., Sun, Y., Zhang, Q., Trimborn, A., Northway, M., Ziemann, P. J., Canagaratna, M. R., Onasch, T. B., Alfarra, M. R., Prevot, A. S. H., Dommen, J., Duplissy, J., Metzger, A., Baltensperger, U., and Jimenez, J. L.: O/C and OM/OC ratios of primary, secondary, and ambient organic aerosols with high-resolution time-of-flight aerosol mass spectrometry, Environ. Sci. Technol., 42, 4478-4485, 2008.

Agarwal, S., Aggarwal, S. G., Okuzawa, K., and Kawamura, K.: Size distributions of dicarboxylic acids, ketoacids, a-dicarbonyls, sugars, WSOC, OC, EC and inorganic ions in atmospheric particles over Northern Japan: implication for long-range transport of Siberian biomass burning and East Asian polluted aerosols, Atmos. Chem. Phys., 10, 5839-5858, doi:10.5194/acp-10-58392010, 2010.

Alterskjær, K., Kristjansson, J. E., and Hoose, C.: Do anthropogenic aerosols enhance or suppress the surface cloud forcing in the Arctic?, J. Geophys. Res., 115, D22204, doi:10.1029/2010JD014015, 2010.

Andreae, M. O. and Rosenfeld, D.: Aerosol-cloudprecipitation interactions. Part 1 . The nature and sources of cloud-active aerosols, Earth-Sci. Rev., 89, 13-41, doi:10.1016/j.earscirev.2008.03.001, 2008.

Asa-Awuku, A., Sullivan, A. P., Hennigan, C. J., Weber, R. J., and Nenes, A.: Investigation of molar volume and surfactant characteristics of water-soluble organic compounds in biomass burning aerosol, Atmos. Chem. Phys., 8, 799-812, doi:10.5194/acp8-799-2008, 2008.

Asa-Awuku, A., Nenes, A., Gao, S., Flagan, R. C., and Seinfeld, J. H.: Water-soluble SOA from Alkene ozonolysis: composition and droplet activation kinetics inferences from analysis of $\mathrm{CCN}$ activity, Atmos. Chem. Phys., 10, 1585-1597, doi:10.5194/acp10-1585-2010, 2010.

Asa-Awuku, A., Moore, R. H., Nenes, A., Bahreini, R., Holloway, J. S., Brock, C. A., Middlebrook, A. M., Ryerson, T., Jimenez, J., DeCarlo, P., Hecobian, A., Weber, R., Stickel, R., Tanner, D. J., and Huey, L. G.: Airborne cloud condensation nuclei measurements during the 2006 Texas Air Quality Study, J. Geophys. Res., 116, D11201, doi:10.1029/2010JD014874, 2011.

Bahreini, R., Dunlea, E. J., Matthew, B. M., Simons, C., Docherty, K. S., DeCarlo, P. F., Jimenez, J. L., Brock, C. A., and Middlebrook, A. M.: Design and operation of a pressure-controlled inlet for airborne sampling with an aerodynamic aerosol lens, Aerosol Sci. Technol., 42, 465-471, doi:10.1080/02786820802178514, 2008.

Bahreini, R., Ervens, B., Middlebrook, A. M., Warneke, C., de Gouw, J. A., DeCarlo, P. F., Jimenez, J. L., Brock, C. A., Neuman, J. A., Ryerson, T. B., Stark, H., Atlas, E., Brioude, J., Fried, A., Holloway, J. S., Peischl, J., Richter, D., Walega, J., Weibring, P., Wollny, A. G., and Fehsenfeld, F. C.: Organic aerosol formation in urban and industrial plumes near Houston and Dallas, Texas, J. Geophys. Res., 114, D00F16, doi:10.1029/2008JD011493, 2009.

Bauer, S. E., Menon, S., Koch, D., Bond, T. C., and Tsigaridis, K.: A global modeling study on carbonaceous aerosol microphysical characteristics and radiative effects, Atmos. Chem. Phys., 10, 7439-7456, doi:10.5194/acp-10-7439-2010, 2010. 
Bougiatioti, A., Fountoukis, C., Kalivitis, N., Pandis, S. N., Nenes, A., and Mihalopoulos, N.: Cloud condensation nuclei measurements in the marine boundary layer of the Eastern Mediterranean: $\mathrm{CCN}$ closure and droplet growth kinetics, Atmos. Chem. Phys., 9, 7053-7066, doi:10.5194/acp-9-7053-2009, 2009.

Bougiatioti, A., Nenes, A., Fountoukis, C., Kalivitis, N., Pandis, S. N., and Mihalopoulos, N.: Size-resolved CCN distributions and activation kinetics of aged continental and marine aerosol, Atmos. Chem. Phys., 11, 8791-8808, doi:10.5194/acp-11-87912011, 2011.

Brock, C. A., Hudson, P. K., Lovejoy, E. R., Sullivan, A., Nowak, J. B., Huey, L. G., Cooper, O. R., Cziczo, D. J., de Gouw, J., Fehsenfeld, F. C., Holloway, J. S., Hübler, G., Lafleur, B. G., Murphy, D. M., Neuman, J. A., Nicks, D. K., Orsini, D. A., Parrish, D. D., Ryerson, T. B., Tanner, D. J., Warneke, C., Weber, R. J., and Wilson J. C.: Particle characteristics following cloud-modified transport from Asia to North America, J. Geophys. Res., 109, D23S26, doi:10.1029/2003JD004198, 2004.

Brock, C. A., Cozic, J., Bahreini, R., Froyd, K. D., Middlebrook, A. M., McComiskey, A., Brioude, J., Cooper, O. R., Stohl, A., Aikin, K. C., de Gouw, J. A., Fahey, D. W., Ferrare, R. A., Gao, R.-S., Gore, W., Holloway, J. S., Hübler, G., Jefferson, A., Lack, D. A., Lance, S., Moore, R. H., Murphy, D. M., Nenes, A., Novelli, P. C., Nowak, J. B., Ogren, J. A., Peischl, J., Pierce, R. B., Pilewskie, P., Quinn, P. K., Ryerson, T. B., Schmidt, K. S., Schwarz, J. P., Sodemann, H., Spackman, J. R., Stark, H., Thomson, D. S., Thornberry, T., Veres, P., Watts, L. A., Warneke, C., and Wollny, A. G.: Characteristics, sources, and transport of aerosols measured in spring 2008 during the aerosol, radiation, and cloud processes affecting Arctic Climate (ARCPAC) Project, Atmos. Chem. Phys., 11, 2423-2453, doi:10.5194/acp-11-24232011, 2011.

Browse, J., Carslaw, K. S., Arnold, S. R., Pringle, K., and Boucher, O.: The scavenging processes controlling the seasonal cycle in Arctic sulphate and black carbon aerosol, Atmos. Chem. Phys., 12, 6775-6798, doi:10.5194/acp-12-6775-2012, 2012.

Cai, Y., Montague, D. C., Mooiweer-Bryan, W., and Deshler, T.: Performance characteristics of the ultra high sensitivity aerosol spectrometer for particles between 55 and $800 \mathrm{~nm}$ : Laboratory and field studies, J. Aerosol Sci., 39, 759-769, doi:10.1016/j.jaerosci.2008.04.007, 2008.

Carrico, C. M., Petters, M. D., Kreidenweis, S. M., Sullivan, A. P., McMeeking, G. R., Levin, E. J. T., Engling, G., Malm, W. C., and Collett Jr., J. L.: Water uptake and chemical composition of fresh aerosols generated in open burning of biomass, Atmos. Chem. Phys., 10, 5165-5178, doi:10.5194/acp-10-5165-2010, 2010.

Cerully, K. M., Raatikainen, T., Lance, S., Tkacik, D., Tiitta, P., Petäjä, T., Ehn, M., Kulmala, M., Worsnop, D. R., Laaksonen, A., Smith, J. N., and Nenes, A.: Aerosol hygroscopicity and CCN activation kinetics in a boreal forest environment during the 2007 EUCAARI campaign, Atmos. Chem. Phys., 11, 12369-12386, doi:10.5194/acp-11-12369-2011, 2011.

Chang, R. Y.-W., Slowik, J. G., Shantz, N. C., Vlasenko, A., Liggio, J., Sjostedt, S. J., Leaitch, W. R., and Abbatt, J. P. D.: The hygroscopicity parameter $(\kappa)$ of ambient organic aerosol at a field site subject to biogenic and anthropogenic influences: relationship to degree of aerosol oxidation, Atmos. Chem. Phys., 10, 5047-5064, doi:10.5194/acp-10-5047-2010, 2010.
Chang, R. Y.-W., Sjostedt, S. J., Pierce, J. R., Papakyriakou, T. N., Scarratt, M. G., Michaud, S., Levasseur, M., Leaitch, W. R., and Abbatt, J. P. D.: Relating atmospheric and oceanic DMS levels to particle nucleation events during the Canadian Arctic Summer, J. Geophys. Res., 116, D00S03, doi:10.1029/2011JD015926, 2011.

Charlson, R. J., Lovelock, J. E., Andreae, M. O., and Warren, S. G.: Oceanic Phytoplankton, Atmospheric Sulfur, Cloud Albedo and Climate, Nature, 326, 655-661, 1987.

Chen, G., Ziemba, L. D., Chu, D. A., Thornhill, K. L., Schuster, G. L., Winstead, E. L., Diskin, G. S., Ferrare, R. A., Burton, S. P., Ismail, S., Kooi, S. A., Omar, A. H., Slusher, D. L., Kleb, M. M., Reid, J. S., Twohy, C. H., Zhang, H., and Anderson, B. E.: Observations of Saharan dust microphysical and optical properties from the Eastern Atlantic during NAMMA airborne field campaign, Atmos. Chem. Phys., 11, 723-740, doi:10.5194/acp11-723-2011, 2011.

Clarke, A., McNaughton, C., Kapustin, V., Shinozuka, Y., Howell, S., Dibb, J., Zhou, J., Anderson, B., Brekhovskikh, V., Turner, H., and Pinkerton, M.: Biomass burning and pollution aerosol over north america: Organic components and their influence on spectral optical properties and humidification response, J. Geophys. Res.-Atmos., 112, D12s18, doi:10.1029/2006jd007777, 2007.

Cubison, M. J., Ortega, A. M., Hayes, P. L., Farmer, D. K., Day, D., Lechner, M. J., Brune, W. H., Apel, E., Diskin, G. S., Fisher, J. A., Fuelberg, H. E., Hecobian, A., Knapp, D. J., Mikoviny, T., Riemer, D., Sachse, G. W., Sessions, W., Weber, R. J., Weinheimer, A. J., Wisthaler, A., and Jimenez, J. L.: Effects of aging on organic aerosol from open biomass burning smoke in aircraft and laboratory studies, Atmos. Chem. Phys., 11, 12049-12064, doi:10.5194/acp-11-12049-2011, 2011.

DeCarlo, P. F., Kimmel, J. R., Trimborn, A., Northway, M. J., Jayne, J. T., Aiken, A. C., Gonin, M., Fuhrer, K., Horvath, T., Docherty, K. S., Worsnop, D. R., and Jimenez, J. L.: Field-deployable, high-resolution, time-of-flight aerosol mass spectrometer, Anal. Chem., 78, 8281-8289, doi:10.1021/ac061249n, 2006.

Duplissy, J., DeCarlo, P. F., Dommen, J., Alfarra, M. R., Metzger, A., Barmpadimos, I., Prevot, A. S. H., Weingartner, E., Tritscher, T., Gysel, M., Aiken, A. C., Jimenez, J. L., Canagaratna, M. R., Worsnop, D. R., Collins, D. R., Tomlinson, J., and Baltensperger, U.: Relating hygroscopicity and composition of organic aerosol particulate matter, Atmos. Chem. Phys., 11, 11551165, doi:10.5194/acp-11-1155-2011, 2011.

Dunlea, E. J., DeCarlo, P. F., Aiken, A. C., Kimmel, J. R., Peltier, R. E., Weber, R. J., Tomlinson, J., Collins, D. R., Shinozuka, Y., McNaughton, C. S., Howell, S. G., Clarke, A. D., Emmons, L. K., Apel, E. C., Pfister, G. G., van Donkelaar, A., Martin, R. V., Millet, D. B., Heald, C. L., and Jimenez, J. L.: Evolution of Asian aerosols during transpacific transport in INTEX-B, Atmos. Chem. Phys., 9, 7257-7287, doi:10.5194/acp-9-7257-2009, 2009.

Dusek, U., Frank, G. P., Massling, A., Zeromskiene, K., Iinuma, Y., Schmid, O., Helas, G., Hennig, T., Wiedensohler, A., and Andreae, M. O.: Water uptake by biomass burning aerosol at suband supersaturated conditions: closure studies and implications for the role of organics, Atmos. Chem. Phys., 11, 9519-9532, doi:10.5194/acp-11-9519-2011, 2011.

Elmendorf, S. C., Henry, G. H. R., Hollister, R. D., Björk, R. G., Boulanger-Lapointe, N., Cooper, E. J., Cornelissen, J. H. C., Day, T. A., Dorrepaal, E., Elumeeva, T. G., Gill, M., Gould, W. A., 
Harte, J., Hik, D. S., Hofgaard, A., Johnson, D. R., Johnstone, J. F., Jónsdóttir, I. S., Jorgenson, J. C., Klanderud, K., Klein, J. A., Koh, S., Kudo, G., Lara, M., Lévesque, E., Magnússon, B., May, J. L., Mercado-Díaz, J. A., Michelsen, A., Molau, U., Myers-Smith, I. H., Oberbauer, S. F., Onipchenko, V. G., Rixen, C., Schmidt, N. M., Shaver, G. R., Spasojevic, M. J., Pórhallsdóttir, P. E., Tolvanen, A., Troxler, T., Tweedie, C. E., Villareal, S., Wahren, C-H., Walker, X., Webber, P. J., Welker, J. M., and Wipf, S.: Plot-Scale Evidence of Tundra Vegetation Change and Links to Recent Summer Warming, Nature Clim. Change, 2, 453-457, doi:10.1038/nclimate1465, 2012.

Engelhart, G. J., Asa-Awuku, A., Nenes, A., and Pandis, S. N.: CCN activity and droplet growth kinetics of fresh and aged monoterpene secondary organic aerosol, Atmos. Chem. Phys., 8, 39373949, doi:10.5194/acp-8-3937-2008, 2008.

Engelhart, G. J., Moore, R. H., Nenes, A., and Pandis, S. N.: Cloud condensation nuclei activity of isoprene secondary organic aerosol, J. Geophys. Res., 116, D02207, doi:10.1029/2010JD014706, 2011.

Engelhart, G. J., Hennigan, C. J., Miracolo, M. A., Robinson, A. L., and Pandis, S. N.: Cloud condensation nuclei activity of fresh primary and aged biomass burning aerosol, Atmos. Chem. Phys., 12, 7285-7293, doi:10.5194/acp-12-7285-2012, 2012.

Farmer, D. K., Matsunaga, A., Docherty, K. S., Surratt, J. D., Seinfeld, J. H., Ziemann, P. J., and Jimenez, J. L.: Response of an Aerosol Mass Spectrometer to Organonitrates and Organosulfates and implications for Atmospheric Chemistry, Proc. Nat. Acad. Sci. USA, 107, 6670-6675, doi:10.1073/pnas.0912340107, 2010.

Fisher, J. A., Jacob, D. J., Purdy, M. T., Kopacz, M., Le Sager, P., Carouge, C., Holmes, C. D., Yantosca, R. M., Batchelor, R. L., Strong, K., Diskin, G. S., Fuelberg, H. E., Holloway, J. S., Hyer, E. J., McMillan, W. W., Warner, J., Streets, D. G., Zhang, Q., Wang, Y., and $\mathrm{Wu}, \mathrm{S}$.: Source attribution and interannual variability of Arctic pollution in spring constrained by aircraft (ARCTAS, ARCPAC) and satellite (AIRS) observations of carbon monoxide, Atmos. Chem. Phys., 10, 977-996, doi:10.5194/acp10-977-2010, 2010.

Frossard, A. A., Shaw, P. M., Russell, L. M., Kroll, J. H., Canagaratna, M. R., Worsnop, D. R., Quinn, P. K., and Bates, T. S.: Springtime Arctic haze contributions of submicron organic particles from European and Asian combustion sources, J. Geophys. Res., 116, D05205, doi:10.1029/2010JD015178, 2011.

Fu, P., Kawamura, K., Chen, J., and Barrie, L. A.: Isoprene, monoterpene, and sesquiterpene oxidation products in the high Arctic aerosols during late winter to early summer, Environ. Sci. Technol., 43, 4022-4028, 2009.

Fuelberg, H. E., Kiley, C., Hannan, J. R., Westberg, D. J., Avery, M. A., and Newell, R. E.: Meteorological conditions and transport pathways during the transport and chemical evolution over the Pacific (TRACE-P) experiment, J. Geophys. Res., 108, 8782, doi:10.1029/2002JD003092, 2003.

Fuelberg, H. E., Harrigan, D. L., and Sessions, W.: A meteorological overview of the ARCTAS 2008 mission, Atmos. Chem. Phys., 10, 817-842, doi:10.5194/acp-10-817-2010, 2010.

Garrett, T. J. and Zhao, C.: Increased arctic cloud longwave emissivity associated with pollution from mid-latitudes, Nature, 440, 787-789, doi:10.1038/nature04636, 2006.
Hand, J. L., Day, D. E., McMeeking, G. M., Levin, E. J. T., Carrico, C. M., Kreidenweis, S. M., Malm, W. C., Laskin, A., and Desyaterik, Y.: Measured and modeled humidification factors of fresh smoke particles from biomass burning: role of inorganic constituents, Atmos. Chem. Phys., 10, 6179-6194, doi:10.5194/acp10-6179-2010, 2010.

Hecobian, A., Liu, Z., Hennigan, C. J., Huey, L. G., Jimenez, J. L., Cubison, M. J., Vay, S., Diskin, G. S., Sachse, G. W., Wisthaler, A., Mikoviny, T., Weinheimer, A. J., Liao, J., Knapp, D. J., Wennberg, P. O., Kürten, A., Crounse, J. D., Clair, J. St., Wang, Y., and Weber, R. J.: Comparison of chemical characteristics of 495 biomass burning plumes intercepted by the NASA DC-8 aircraft during the ARCTAS/CARB-2008 field campaign, Atmos. Chem. Phys., 11, 13325-13337, doi:10.5194/acp-1113325-2011, 2011.

Heintzenberg, J. and Leck, C.: The summer aerosol in the central Arctic 1991-2008: did it change or not?, Atmos. Chem. Phys., 12, 3969-3983, doi:10.5194/acp-12-3969-2012, 2012.

Hennigan, C. J., Bergin, M. H., Dibb, J. E., and Weber, R. J.: Enhanced secondary organic aerosol formation due to water uptake by fine particles, Geophys. Res. Lett., 35, L18801, doi:10.1029/2008GL035046, 2008.

Hornbrook, R. S., Blake, D. R., Diskin, G. S., Fried, A., Fuelberg, H. E., Meinardi, S., Mikoviny, T., Richter, D., Sachse, G. W., Vay, S. A., Walega, J., Weibring, P., Weinheimer, A. J., Wiedinmyer, C., Wisthaler, A., Hills, A., Riemer, D. D., and Apel, E. C.: Observations of nonmethane organic compounds during ARCTAS - Part 1: Biomass burning emissions and plume enhancements, Atmos. Chem. Phys., 11, 11103-11130, doi:10.5194/acp11-11103-2011, 2011.

Huffman, J.A., Jayne, J. T., Drewnick, F., Aiken, A. C., Onasch, T., Worsnop, D. R., and Jimenez, J. L.: Design, Modeling, Optimization, and Experimental Tests of a Particle Beam Width Probe for the Aerodyne Aerosol Mass Spectrometer, Aerosol Sci. Technol., 39, 1143-1163, doi:10.1080/02786820500423782, 2005.

Jacob, D. J., Crawford, J. H., Maring, H., Clarke, A. D., Dibb, J. E., Emmons, L. K., Ferrare, R. A., Hostetler, C. A., Russell, P. B., Singh, H. B., Thompson, A. M., Shaw, G. E., McCauley, E., Pederson, J. R., and Fisher, J. A.: The Arctic Research of the Composition of the Troposphere from Aircraft and Satellites (ARCTAS) mission: design, execution, and first results, Atmos. Chem. Phys., 10, 5191-5212, doi:10.5194/acp-10-5191-2010, 2010.

Jimenez, J. L., Jayne, J. T., Shi, Q., Kolb, C. E., Worsnop, D. R., Yourshaw, I., Seinfeld, J. H., Flagan, R. C., Zhang, X. F., Smith, K. A., Morris, J. W., and Davidovits, P.: Ambient aerosol sampling using the Aerodyne Aerosol Mass Spectrometer, J. Geophys. Res., 108, 8425, doi:10.1029/2001JD001213, 2003.

Jimenez, J. L., Canagaratna, M. R., Donahue, N. M., Prevot, A. S. H., Zhang, Q., Kroll, J. H., DeCarlo, P. F., Allan, J. D., Coe, H., Ng, N. L., Aiken, A. C., Docherty, K. S., Ulbrich, I. M., Grieshop, A. P., Robinson, A. L., Duplissy, J., Smith, J. D., Wilson, K. R., Lanz, V. A., Hueglin, C., Sun, Y. L., Tian, J., Laaksonen, A., Raatikainen, T., Rautiainen, J., Vaattovaara, P., Ehn, M., Kulmala, M., Tomlinson, J. M., Collins, D. R., Cubison, M. J., Dunlea, E. J., Huffman, J. A., Onasch, T. B., Alfarra, M. R., Williams, P. I., Bower, K., Kondo, Y., Schneider, J., Drewnick, F., Borrmann, S., Weimer, S., Demerjian, K., Salcedo, D., Cottrell, L., Griffin, R., Takami, A., Miyoshi, T., Hatakeyama, S., Shimono, A., Sun, J. Y., Zhang, Y. M., Dzepina, K., Kimmel, J. 
R., Sueper, D., Jayne, J. T., Herndon, S. C., Trimborn, A. M., Williams, L. R., Wood, E. C., Middlebrook, A. M., Kolb, C. E., Baltensperger, U., and Worsnop, D. R.: Evolution of Organic Aerosols in the Atmosphere, Science, 326, 1525-1529, 2009.

Jurányi, Z., Gysel, M., Weingartner, E., DeCarlo, P. F., Kammermann, L., and Baltensperger, U.: Measured and modelled cloud condensation nuclei number concentration at the high alpine site Jungfraujoch, Atmos. Chem. Phys., 10, 7891-7906, doi:10.5194/acp-10-7891-2010, 2010.

Kammermann, L., Gysel, M., Weingartner, E., Herich, H., Cziczo, D. J., Holst, T., Svenningsson, B., Ameth, A., and Baltensperger, U.: Subarctic atmospheric aerosol composition: 3. Measured and modeled properties of cloud condensation nuclei, J. Geophys. Res., 115, D04202, doi:10.1029/2009JD012447, 2010.

Kanakidou, M., Seinfeld, J. H., Pandis, S. N., Barnes, I., Dentener, F. J., Facchini, M. C., Van Dingenen, R., Ervens, B., Nenes, A., Nielsen, C. J., Swietlicki, E., Putaud, J. P., Balkanski, Y., Fuzzi, S., Horth, J., Moortgat, G. K., Winterhalter, R., Myhre, C. E. L., Tsigaridis, K., Vignati, E., Stephanou, E. G., and Wilson, J.: Organic aerosol and global climate modelling: a review, Atmos. Chem. Phys., 5, 1053-1123, doi:10.5194/acp-5-1053-2005, 2005.

King, S. M., Rosenoern, T., Shilling, J. E., Chen, Q, and Martin, S. T.: Cloud condensation nucleus activity of secondary organic aerosol particles mixed with sulfate, Geophys. Res. Lett., 34, L24806, doi:10.1029/2007GL030390, 2007.

Köhler, H.: The nucleus in and growth of hygroscopic droplets, Trans. Faraday Soc., 32, 1152-1161, doi:10.1039/TF9363201152, 1936.

Kondo, Y., Matsui, H., Moteki, N., Sahu, L., Takegawa, N., Kajino, M., Zhao, Y., Cubison, M. J., Jimenez, J. L., Vay, S., Diskin, G. S., Anderson, B., Wisthaler, A., Mikoviny, T., Fuelberg, H. E., Blake, D. R., Huey, G., Weinheimer, A. J., Knapp, D. J., and Brune, W. H.: Emissions of black carbon, organic, and inorganic aerosols from biomass burning in North America and Asia in 2008, J. Geophys. Res.-Atmos., 116, D08204, doi:10.1029/2010JD015152, 2011.

Kumar, P., Sokolik, I. N., and Nenes, A.: Measurements of cloud condensation nuclei activity and droplet activation kinetics of fresh unprocessed regional dust samples and minerals, Atmos. Chem. Phys., 11, 3527-3541, doi:10.5194/acp-11-3527-2011, 2011.

Kuwata, M., Zorn, S. R., and Martin, S. T.: Using Elemental Ratios to Predict the Density of Organic Material Composed of Carbon, Hydrogen, and Oxygen, Environ. Sci. Technol., 46, 787794, doi:10.1021/es202525q, 2012.

Lambe, A. T., Onasch, T. B., Massoli, P., Croasdale, D. R., Wright, J. P., Ahern, A. T., Williams, L. R., Worsnop, D. R., Brune, W. H., and Davidovits, P.: Laboratory studies of the chemical composition and cloud condensation nuclei $(\mathrm{CCN})$ activity of secondary organic aerosol (SOA) and oxidized primary organic aerosol (OPOA), Atmos. Chem. Phys., 11, 8913-8928, doi:10.5194/acp11-8913-2011, 2011.

Lance, S., Medina, J., Smith, J. N., and Nenes, A.: Mapping the operation of the DMT continuous-flow CCN counter, Aerosol Sci. Technol., 40, 242-254, doi:10.1080/02786820500543290, 2006.

Lance, S., Shupe, M. D., Feingold, G., Brock, C. A., Cozic, J., Holloway, J. S., Moore, R. H., Nenes, A., Schwarz, J. P., Spackman, J. R., Froyd, K. D., Murphy, D. M., Brioude, J., Cooper,
O. R., Stohl, A., and Burkhart, J. F.: Cloud condensation nuclei as a modulator of ice processes in Arctic mixed-phase clouds, Atmos. Chem. Phys., 11, 8003-8015, doi:10.5194/acp-11-80032011, 2011.

Lathem, T. L. and Nenes, A.: Water vapor depletion in the DMT Continuous Flow CCN Chamber: effects on supersaturation and droplet growth, Aerosol Sci. Technol., 45, 604-615, doi:10.1080/02786826.2010.551146, 2011.

Lathem, T. L., Kumar, P., Nenes, A., Dufek, J., Sokolik, I. N., Trail, M., and Russell, A.: Hygroscopic properties of volcanic ash, Geophys. Res. Lett., 38, L11802, doi:10.1029/2011GL047298, 2011.

Law, K. S. and Stohl, A.: Arctic air pollution: Origins and impacts, Science, 315, 1537-1540, doi:10.1126/science.1137695, 2007.

Leaitch, W. R., Hoff, R. M., Melnichuk, S., and Hogan, W.: Some chemical and physical properties of the Arctic winter aerosol in northeastern Canada, J. Climate Appl. Meteorol., 23, 916-928, 1983.

Leaitch, W. R., Barrie, L. A., Bottenheim, J. W., Li, S.-M., Shepson, P., and Yokouchi, Y.: Airborne observations related ozone depletion at polar sunrise, J. Geophys. Res., 99, 25499-25517, 1994.

Leck, C. and Persson, C.: The central Arctic Ocean as a source of dimethyl sulfide: Seasonal variability in relation to biological activity, Tellus, 48B, 156-177, 1996.

Leck, C., Norman, M., Bigg, E. K., and Hillamo, R.: Chemical composition and sources of the high Arctic aerosol relevant for cloud formation, J. Geophys. Res., 107, 4135, doi:10.1029/2001JD001463, 2002.

Lubin, D. and Vogelmann, A. M.: A climatologically significant aerosol longwave indirect effect in the Arctic, Nature, 439, 453456, doi:10.1038/nature04449, 2006.

Mann, G. W., Carslaw, K. S., Spracklen, D. V., Ridley, D. A., Manktelow, P. T., Chipperfield, M. P., Pickering, S. J., and Johnson, C. E.: Description and evaluation of GLOMAP-mode: a modal global aerosol microphysics model for the UKCA composition-climate model, Geosci. Model Dev., 3, 519-551, doi:10.5194/gmd-3-519-2010, 2010.

Marcolli, C., Luo, B. P., Peter, Th., and Wienhold, F. G.: Internal mixing of the organic aerosol by gas phase diffusion of semivolatile organic compounds, Atmos. Chem. Phys., 4, $2593-$ 2599, doi:10.5194/acp-4-2593-2004, 2004.

Martin, M., Chang, R. Y.-W., Sierau, B., Sjogren, S., Swietlicki, E., Abbatt, J. P. D., Leck, C., and Lohmann, U.: Cloud condensation nuclei closure study on summer arctic aerosol, Atmos. Chem. Phys., 11, 11335-11350, doi:10.5194/acp-11-11335-2011, 2011.

Matsui, H., Kondo, Y., Moteki, N., Takegawa, N., Sahu, L. K., Zhao, Y., Fuelberg, H. E., Sessions, W. R., Diskin, G., Blake, D. R., Wisthaler, A., and Koike, M.: Seasonal variation of the transport of black carbon aerosol from the Asian continent to the Arctic during the ARCTAS aircraft campaign, J. Geophys. Res.-Atmos., 116, D05202, doi:10.1029/2010JD015067, 2011.

Mauritsen, T., Sedlar, J., Tjernström, M., Leck, C., Martin, M., Shupe, M., Sjogren, S., Sierau, B., Persson, P. O. G., Brooks, I. M., and Swietlicki, E.: An Arctic CCN-limited cloud-aerosol regime, Atmos. Chem. Phys., 11, 165-173, doi:10.5194/acp-11165-2011, 2011.

McLinden, C. A., Fioletov, V., Boersma, K. F., Krotkov, N., Sioris, C. E., Veefkind, J. P., and Yang, K.: Air quality over the Cana- 
dian oil sands: A first assessment using satellite observations, Geophys. Res. Lett., 39, L04804, doi:10.1029/2011GL050273, 2012.

McNaughton, C. S., Clarke, A. D., Howell, S. G., Pinkerton, M., Anderson, B., Thornhill, L., Hudgins, C., Winstead, E., Dibb, J. E., Scheuer, E., and Maring, H.: Results from the dc-8 inlet characterization experiment (dice): Airborne versus surface sampling of mineral dust and sea salt aerosols, Aerosol Sci. Technol., 41, 136-159, doi:10.1080/02786820601118406, 2007.

Meskhidze, N., Xu, J., Gantt, B., Zhang, Y., Nenes, A., Ghan, S. J., Liu, X., Easter, R., and Zaveri, R.: Global distribution and climate forcing of marine organic aerosol: 1. Model improvements and evaluation, Atmos. Chem. Phys., 11, 11689-11705, doi:10.5194/acp-11-11689-2011, 2011.

Middlebrook, A.M., Bahreini, R., Jimenez, J. L., and Canagaratna, M. R.: Evaluation of Composition-Dependent Collection Efficiencies for the Aerodyne Aerosol Mass Spectrometer using Field Data, Aerosol Sci. Technol., 46, 258-271, doi:10.1080/02786826.2011.620041, 2012.

Moore, R. H., Nenes, A., and Medina, J.: Scanning mobility CCN analysis-a method for fast measurements of size-resolved CCN distributions and activation kinetics, Aerosol Sci. Tech., 44, 861871, 2010.

Moore, R. H., Bahreini, R., Brock, C. A., Froyd, K. D., Cozic, J., Holloway, J. S., Middlebrook, A. M., Murphy, D. M., and Nenes, A.: Hygroscopicity and composition of Alaskan Arctic CCN during April 2008, Atmos. Chem. Phys., 11, 11807-11825, doi:10.5194/acp-11-11807-2011, 2011.

Moore, R. H., Karydis, V. A., Capps, S. L., Lathem, T. L., and Nenes, A.: Droplet number prediction uncertainties from $\mathrm{CCN}$ : an integrated assessment using observations and a global adjoint model, Atmos. Chem. Phys. Discuss., 12, 20483-20517, doi:10.5194/acpd-12-20483-2012, 2012.

Nenes, A., Pandis, S. N., and Pilinis, C.: ISORROPIA: A new thermodynamic equilibrium model for multiphase multicomponent aerosols, Aquat. Geochem., 4, 123-152, doi:10.1023/A:1009604003981, 1998.

Ng, N. L., Canagaratna, M. R., Jimenez, J. L., Chhabra, P. S., Seinfeld, J. H., and Worsnop, D. R.: Changes in organic aerosol composition with aging inferred from aerosol mass spectra, Atmos. Chem. Phys., 11, 6465-6474, doi:10.5194/acp-11-64652011, 2011.

Orellana, M. V., Matrai, P., Leck, C., Rauschenberg, C. D., Lee, A. M, and Coz, E.: Marine microgels as a source of cloud condensation nuclei in the high Arctic, Proc. Natl. Acad. Sci., 108, 13612-13617, 2011.

Padró, L. T., Tkacik, D., Lathem, T. L., Hennigan, C. J., Sullivan, A. P., Weber, R. J., Huey, L. G., and Nenes, A.: Investigation of cloud condensation nuclei properties and droplet growth kinetics of the water-soluble aerosol fraction in Mexico City, J. Geophys. Res., 115, D09204, doi:10.1029/2009JD013195, 2010.

Petters, M. D. and Kreidenweis, S. M.: A single parameter representation of hygroscopic growth and cloud condensation nucleus activity, Atmos. Chem. Phys., 7, 1961-1971, doi:10.5194/acp-71961-2007, 2007.

Petters, M. D., Carrico, C. M., Kreidenweis, S. M., Prenni, A. J., DeMott, P. J., Collett, J. L., and Moosmüler, H.: Cloud condensation nucleation activity of biomass burning aerosol, J. Geophys. Res., 114, D22205, doi:10.1029/2009JD012353, 2009.
Pratt, K. A., Murphy, S. M., Subramanian, R., DeMott, P. J., Kok, G. L., Campos, T., Rogers, D. C., Prenni, A. J., Heymsfield, A. J., Seinfeld, J. H., and Prather, K. A.: Flight-based chemical characterization of biomass burning aerosols within two prescribed burn smoke plumes, Atmos. Chem. Phys., 11, 1254912565, doi:10.5194/acp-11-12549-2011, 2011.

Prenni, A. J., Harrington, J. Y., Tjernström, M., DeMott, P. J., Avramov, A., Long, C. N., Kreidenweis, S. M., Olsson, P. Q., and Verlinde, J.: Can ice-nucleating aerosols affect Arctic seasonal climate?, Bull. Amer. Meteorol. Soc., 88, 541-550, doi:10.1175/BAMS-88-4-541, 2007.

Pringle, K. J., Tost, H., Pozzer, A., Pöschl, U., and Lelieveld, J.: Global distribution of the effective aerosol hygroscopicity parameter for $\mathrm{CCN}$ activation, Atmos. Chem. Phys., 10, 52415255, doi:10.5194/acp-10-5241-2010, 2010.

Quinn, P. K., Shaw, G., Andrews, E., Dutton, E. G., RuohoAirola, T., and Gong, S. L.: Arctic haze: current trends and knowledge gaps, Tellus B, 59B, 99-114, doi:10.1111/j.16000889.2006.00238.x, 2007.

Quinn, P. K., Bates, T. S., Baum, E., Doubleday, N., Fiore, A. M., Flanner, M., Fridlind, A., Garrett, T. J., Koch, D., Menon, S., Shindell, D., Stohl, A., and Warren, S. G.: Short-lived pollutants in the Arctic: their climate impact and possible mitigation strategies, Atmos. Chem. Phys., 8, 1723-1735, doi:10.5194/acp8-1723-2008, 2008.

Quinn, P. K., Bates, T. S., Schulz, K., and Shaw, G. E.: Decadal trends in aerosol chemical composition at Barrow, Alaska: 19762008, Atmos. Chem. Phys., 9, 8883-8888, doi:10.5194/acp-98883-2009, 2009.

Raatikainen, T., Moore, R. H., Lathem, T. L., and Nenes, A.: A coupled observation - modeling approach for studying activation kinetics from measurements of CCN activity, Atmos. Chem. Phys., 12, 4227-4243, doi:10.5194/acp-12-4227-2012, 2012.

Raatikainen,T., Nenes,A., Seinfeld, J. H., Morales,R., Moore, R. H., Lathem, T. L., Lance, S., Padro, L. T., Lin, J. J., Cerully, K., Bougiatioti, A., Cozic, J., Ruehl, C., Chuang, P. Y., Anderson, B., Flagan, R. C., Jonsson, H., Mihalopoulos, N., and Smith, J. N.: Worldwide data sets constrain the water vapor uptake coefficient in cloud formation, P. Natl. Acad. Sci., 110, 3760-3764, doi:10.1073/pnas.1219591110, 2013.

Reid, J. S., Koppmann, R., Eck, T. F., and Eleuterio, D. P.: A review of biomass burning emissions part II: intensive physical properties of biomass burning particles, Atmos. Chem. Phys., 5, 799825, doi:10.5194/acp-5-799-2005, 2005.

Roberts, G. C. and Nenes, A.: A continuous-flow streamwise thermal-gradient $\mathrm{CCN}$ chamber for atmospheric measurements, Aerosol Sci. Technol., 39, 206-221, doi:10.1080/027868290913988, 2005.

Russell, L. M.: Aerosol organic-mass-to-organic-carbon ratio measurements, Environ. Sci. Technol., 37, 2982-2987, 2003.

Scheuer, E., Talbot, R. W., Dibb, J. E., Seid, G. K., deBell, L., and Lefer, G.: Seasonal distributions of fine aerosol sulfate in the North American Arctic Basin during TOPSE, J. Geophys. Res., 108, 8370, doi:10.1029/2001JD001364, 2003.

Screen, J. A., Deser, C., and Simmonds, I.: Local and remote controls on observed Arctic warming, Geophys. Res. Lett., 39, L10709, doi:10.1029/2012GL051598, 2012. 
Shaw, G. E.: The Arctic haze phenomenon, B. Am. Meteorol. Soc., 76, 2403-2413, doi:10.1175/15200477(1995)076<2403:TAHP>2.0.CO;2, 1995.

Shaw, P. M., Russell, L. M., Jefferson, A., and Quinn, P. K.: Arctic organic aerosol measurements show particles from mixed combustion in spring haze and from frost flowers in winter, Geophys. Res. Lett., 37, L10803, doi:10.1029/2010GL042831, 2010.

Shindell, D. and Faluvegi, G.: Climate response to regional radiative forcing during the twentieth century, Nature Geosci., 2, 294-300, doi:10.1038/ngeo473, 2009.

Shindell, D. T., Chin, M., Dentener, F., Doherty, R. M., Faluvegi, G., Fiore, A. M., Hess, P., Koch, D. M., MacKenzie, I. A., Sanderson, M. G., Schultz, M. G., Schulz, M., Stevenson, D. S., Teich, H., Textor, C., Wild, O., Bergmann, D. J., Bey, I., Bian, H., Cuvelier, C., Duncan, B. N., Folberth, G., Horowitz, L. W., Jonson, J., Kaminski, J. W., Marmer, E., Park, R., Pringle, K. J., Schroeder, S., Szopa, S., Takemura, T., Zeng, G., Keating, T. J., and Zuber, A.: A multi-model assessment of pollution transport to the Arctic, Atmos. Chem. Phys., 8, 5353-5372, doi:10.5194/acp-85353-2008, 2008.

Sihto, S.-L., Mikkilä, J., Vanhanen, J., Ehn, M., Liao, L., Lehtipalo, K., Aalto, P. P., Duplissy, J., Petäjä, T., Kerminen, V.-M., Boy, M., and Kulmala, M.: Seasonal variation of CCN concentrations and aerosol activation properties in boreal forest, Atmos. Chem. Phys., 11, 13269-13285, doi:10.5194/acp-11-13269-2011, 2011.

Simpson, I. J., Blake, N. J., Barletta, B., Diskin, G. S., Fuelberg, H. E., Gorham, K., Huey, L. G., Meinardi, S., Rowland, F. S., Vay, S. A., Weinheimer, A. J., Yang, M., and Blake, D. R.: Characterization of trace gases measured over Alberta oil sands mining operations: 76 speciated $\mathrm{C}_{2}-\mathrm{C}_{10}$ volatile organic compounds (VOCs), $\mathrm{CO}_{2}, \mathrm{CH}_{4}, \mathrm{CO}, \mathrm{NO}, \mathrm{NO}_{2}, \mathrm{NO}_{\mathrm{y}}, \mathrm{O}_{3}$ and $\mathrm{SO}_{2}$, Atmos. Chem. Phys., 10, 11931-11954, doi:10.5194/acp-10-11931-2010, 2010.

Singh, H. B., Anderson, B. E., Brune, W. H., Cai, C., Cohen, R. C., Crawford, J. H., Cubison, M. J., Czech, E. P., Emmons, L., Fuelberg, H. E., Huey, G., Jacob, D. J., Jimenez, J. L., Kaduwela, A., Kondo, Y., Mao, J., Olson, J. R., Sachse, G. W., Vay, S. A., Weinheimer, A., Wennberg, P. O., and Wisthaler, A.: Pollution Influences on Atmospheric Composition and Chemistry at High Northern Latitudes: Boreal and California Forest Fire Emissions, Atmos. Environ., 44, 4553-4564, 2010.

Slowik, J. G., Stroud, C., Bottenheim, J. W., Brickell, P. C., Chang, R. Y.-W., Liggio, J., Makar, P. A., Martin, R. V., Moran, M. D., Shantz, N. C., Sjostedt, S. J., van Donkelaar, A., Vlasenko, A., Wiebe, H. A., Xia, A. G., Zhang, J., Leaitch, W. R., and Abbatt, J. P. D.: Characterization of a large biogenic secondary organic aerosol event from eastern Canadian forests, Atmos. Chem. Phys., 10, 2825-2845, doi:10.5194/acp-10-2825-2010, 2010.

Spracklen, D. V., Bonn, B., and Carslaw, K. S.: Boreal Forests, Aerosols and the Impacts on Clouds and Climate, Philos. Trans. Roy. Soc. A., 366, 4613-4626, doi:10.1098/rsta.2008.0201, 2008.

Sotiropoulou, R.-E. P., Nenes, A., Adams, P. J., and Seinfeld, J. H.: Cloud condensation nuclei prediction error from application of Köhler theory: Importance for the aerosol indirect effect, J. Geophys. Res., 112, D12202, doi:10.1029/2006JD007834, 2007.

Stohl, A.: A 1-year Lagrangian "climatology" of air streams in the Northern Hemisphere troposphere and lower stratosphere, J. Geophys. Res., 106, 7263-7279, 2001.
Stohl, A., Andrews, E., Burkhart, J. F., Forster, C., Herber, A., Hoch, S. W., Kowal, D., Lunder, C., Mefford, T., Ogren, J. A., Sharma, S., Spichtinger, N., Stebel, K., Stone, R., Ström, J., Tørseth, K., Wehrli, C., and Yttri, K. E.: Pan-Arctic enhancements of light absorbing aerosol concentrations due to North American boreal forest fires during summer 2004, J. Geophys. Res., 111, D22214, doi:10.1029/2006JD007216, 2006.

Stohl, A., Berg, T., Burkhart, J. F., Fjæraa, A. M., Forster, C., Herber, A., Hov, Ø., Lunder, C., McMillan, W. W., Oltmans, S., Shiobara, M., Simpson, D., Solberg, S., Stebel, K., Ström, J., Tørseth, K., Treffeisen, R., Virkkunen, K., and Yttri, K. E.: Arctic smoke - record high air pollution levels in the European Arctic due to agricultural fires in Eastern Europe in spring 2006, Atmos. Chem. Phys., 7, 511-534, doi:10.5194/acp-7-511-2007, 2007.

Suda, S. R., Petters, M. D., Matsunaga, A., Sullivan, R. C., Ziemann, P. J., and Kreidenweis, S. M.: Hygroscopicity frequency distributions of secondary organic aerosols, J. Geophys. Res. 117, D04207, doi:10.1029/2011JD016823, 2012.

Sullivan, A. P., Weber, R. J., Clements, A. L., Turner, J. R., Bae, M. S., and Schauer, J. J.: A method for on-line measurement of water-souble organic carbon in ambient aerosol particles: Results from an urban site, Geophys. Res. Lett., L13105, doi:10.1029/2004GL019681, 2004.

Sullivan, A. P., Peltier, R. E., Brock, C. A., de Gouw, J. A., Holloway, J. S., Warneke, C., Wollny, A. G., and Weber, R. J.: Airborne measurements of carbonaceous aerosol soluble in water over northeastern United States: Method development and an investigation into water-soluble organic carbon sources, J. Geophys. Res., 111, D23S46, doi:10.1029/2006JD007072, 2006.

Thornhill, K. L., Chen, G., Dibb, J., Jordan, C. E., Omar, A., Winstead, E. L., Schuster, G., Clarke, A., McNaughton, C., Scheuer, E., Blake, D., Sachse, G., Huey, L. G., Singh, H. B., and Anderson, B. E.: The impact of local sources and longrange transport on aerosol properties over the northeast U.S region during INTEX-NA, J. Geophys. Res.-Atmos., 113, D08201, doi:10.1029/2007jd008666, 2008.

Tietze, K., Riedi, J., Stohl, A., and Garrett, T. J.: Space-based evaluation of interactions between aerosols and low-level Arctic clouds during the Spring and Summer of 2008, Atmos. Chem. Phys., 11, 3359-3373, doi:10.5194/acp-11-3359-2011, 2011.

Turpin, B. J. and Lim, H. J.: Species contribution to PM2.5 mass concentrations: Revisiting common assumptions for estimating organic mass, Aerosol Sci. Technol., 35, 602-610, 2001.

Twomey, S.: The influence of pollution on the shortwave albedo of clouds, J. Atmos. Sci., 34, 1149-1152, doi:10.1175/15200469(1977)034<1149:TIOPOT>2.0.CO;2, 1977.

Wang, J., Cubison, M. J., Aiken, A. C., Jimenez, J. L., and Collins, D. R.: The importance of aerosol mixing state and size-resolved composition on $\mathrm{CCN}$ concentration and the variation of the importance with atmospheric aging of aerosols, Atmos. Chem. Phys., 10, 7267-7283, doi:10.5194/acp-10-7267-2010, 2010.

Warneke, C., Bahreini, R., Brioude, J., Brock, C. A., de Gouw, J. A., Fahey, D. W., Froyd, K. D., Holloway, J. S., Middlebrook, A., Miller, L., Montzka, S., Murphy, D. M., Peischl, J., Ryerson, T. B., Schwarz, J. P., Spackman, J. R., and Veres, P.: Biomass burning in Siberia and Kazakhstan as an important source for haze over the Alaskan Arctic in April 2008, Geophys. Res. Lett., 36, L02813, doi:10.1029/2008GL036194, 2009. 
Warneke, C., Froyd, K. D., Brioude, J., Bahreini, R., Brock, C. A., Cozic, J., de Gouw, J. A., Fahey, D. W., Ferrare, R., Holloway, J. S., Middlebrook, A. M., Miller, L., Montzka, S., Schwarz, J. P., Sodemann, H., and Spackman, J. R.: An important contribution to springtime Arctic aerosol from biomass burning in Russia, Geophys. Res. Lett., 37, L01801, doi:10.1029/2009GL041816, 2010 .
Zhang, Y., Karamchandani, P., Glotfelty, T., Streets, D. G., Skamarock, W. C., Grell, G., Nenes, A., Yu, F., and Bennartz, R.: Development and Initial Application of the GlobalThrough-Urban Weather Research and Forecasting Model with Chemistry (GU-WRF/Chem), J. Geophys. Res., 117, D20206, doi:10.1029/2012JD017966, 2012. 